The Free Internet Journal

for Organic Chemistry
Review

Arkivoc 2018, part i, 0-0

Organic Chemistry

\title{
Recent syntheses of ellipticine and its derivatives
}

\author{
Malika Ibrahim-Ouali*a and Frédéric Dumur ${ }^{b}$ \\ ${ }^{a}$ Aix Marseille Univ, CNRS, Centrale Marseille, iSm2, UMR 7313, F-13397, Marseille, France \\ ${ }^{b}$ Aix Marseille Univ, CNRS, Institut de Chimie Radicalaire ICR, UMR 7273, F-13397, Marseille, France \\ Email address: malika.ibrahim@univ-amu.fr
}

Received 12-09-2017

Accepted 02-25-2018

Published on line $04-24-2018$

\section{Abstract}

The pyrido[4,3-b]carbazole alkaloid, ellipticine, was attracting considerable interest for many years due to its pronounced antitumor activity. We review the most important achievements in the field of ellipticine synthesis and its derivatives since 2012.

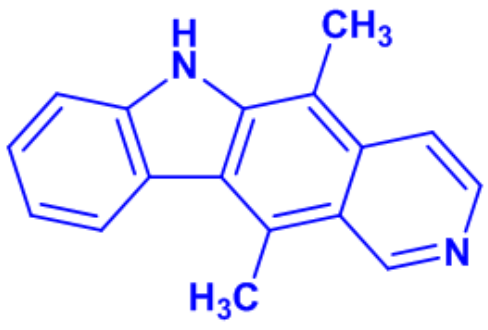

Ellipticine

Keywords: Ellipticine, ellipticine derivatives, alkaloids, synthesis 


\section{Table of Contents}

1. Introduction

2. Synthesis of Ellipticine and Derivatives

3. Conclusions

4. Acknowledgements

References

\section{Introduction}

The natural plant product ellipticine ${ }^{1-7}$ was isolated in 1959 from the Australian evergreen tree, Ochrosia elliptica, of the Apocynaccae Apocynaceae. This compound was found to be a promising anticancer drug. So, the syntheses of ellipticine and its derivatives have been reported by many groups. ${ }^{8-27}$

The planar polycyclic structure was found to interact with DNA through intercalation, exhibiting a high DNA binding affinity $\left(10^{6} \mathrm{M}^{-1}\right)$. The presence of protonatable ring nitrogens distinguished ellipticine from other simple intercalators. Both monocationic and uncharged species were found to be present under physiological conditions. The position charge stabilized the binding of ellipticine to nucleic acids, while the more lipophilic uncharged compound was shown to readily penetrate membrane barriers. The structural nature of these compounds offers a plausible basis for the implication of multiple modes of action, including DNA binding, interactions with membrane barriers, oxidative bioactivation and modification of enzyme function; most notably that of topoisomerase II and telomerase. Pharmaceutically, a number of toxic side effects have been shown to be problematic, but the amenability of ellipticine towards systematic structural modification has permitted the extensive application of rational drug design. A number of successful ellipticine analogs have been designed and synthesized with improved toxicities and anticancer activities. ${ }^{28-29}$ More recently the synthetic focus has broadened to include the design of hybrid compounds, as well as drug delivery conjugates. Considerable research efforts have been directed towards gaining a greater understanding of the mechanism of action of these drugs that will aid further in the optimization of drug design.

This article provide an overview of the various syntheses of ellipticine from the years 2013 to 2017. Although a previous review by McCarthy et al. has appeared in 2012, ${ }^{30}$ some reports were missing from their compilation. Thus, we have chosen to cover the literature under one section up to December 2017, omitting those works which have already been reported in the previous review.

\section{Synthesis of Ellipticine and Derivatives}

In 2014, Meesala et al. $^{31}$ have developed a simple and an efficient method to synthesize a new series of ellipticine analogues using the Vilsmeier-Haack reagent (Scheme 1). They described the synthesis of pyrido[3,2-b]carbazoles and pyrido[2,3-c]carbazoles by treating $\mathrm{N}$-(carbazol-3-yl)acetamides 1a-e with DMF (2.5 equiv) and $\mathrm{POCl}_{3}$ (10.0 equiv) at $70{ }^{\circ} \mathrm{C}$ for 12 hours. The reaction works well with different types of $N$ (carbazol-3-yl)acetamide derivatives and provides the corresponding linear and angular products. The angular products were obtained as the major isomers compared to the linear products.

Since the pyridocarbazoles contain the reactive substituents chlorine and aldehyde, these can be utilized for further heteroannulations to develop novel pyridocarbazole-based heterocyclic systems which may exhibit interesting biological properties. 


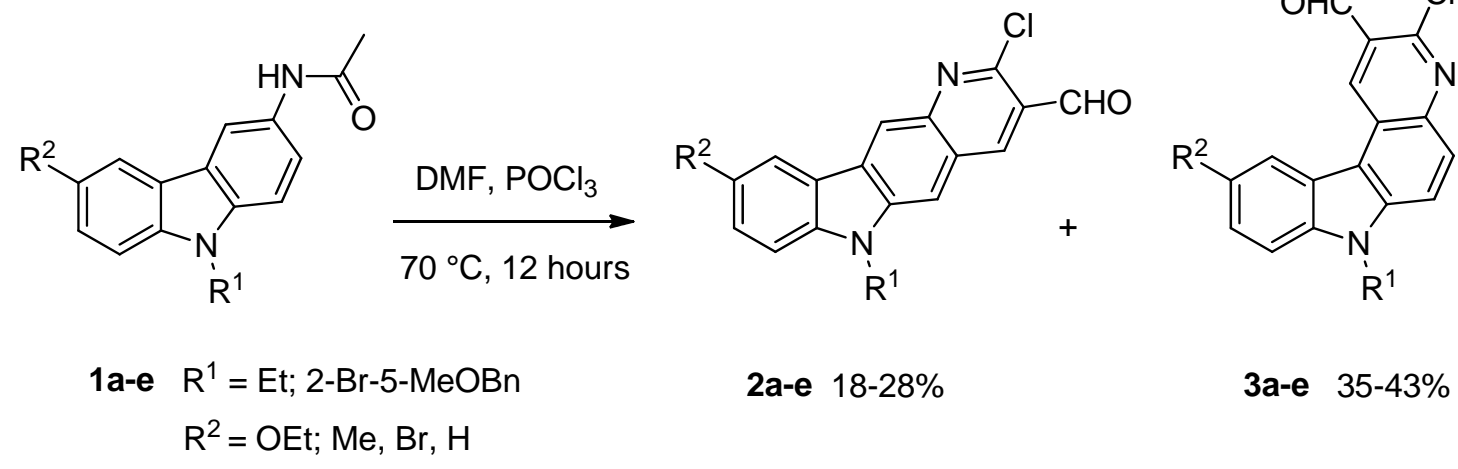

Scheme 1. Synthesis of pyridocarbazoles 2 and 3.

Nagarajan et al. ${ }^{32}$ reported a simple and efficient route to the synthesis of ellipticine quinone 12 (Scheme 3) from isatin 4. The first key step is the synthesis of $\mathbf{7}$ from isatin using various alkylating reagents (Scheme 2). They performed reaction between sodium 2-(2-aminophenyl)-2-oxoacetate 5 and 2-bromo-1-(pyridin-4$\mathrm{yl}$ )ethanone hydrobromide in DMF at $70{ }^{\circ} \mathrm{C}$ for $5 \mathrm{~h}$ affording $7 \mathrm{in} 17 \%$ yield. The next step is the rearrangement of $\mathbf{7}$ to carboxylic acid $\mathbf{9}$. Hydrolysis of compound $\mathbf{7}$ afforded $\mathbf{9}$ through an intermediate $\mathbf{8}$ along with easily separable decarboxilated product 10 in $76 \%$ and $24 \%$ yield respectively (Scheme 3 ).

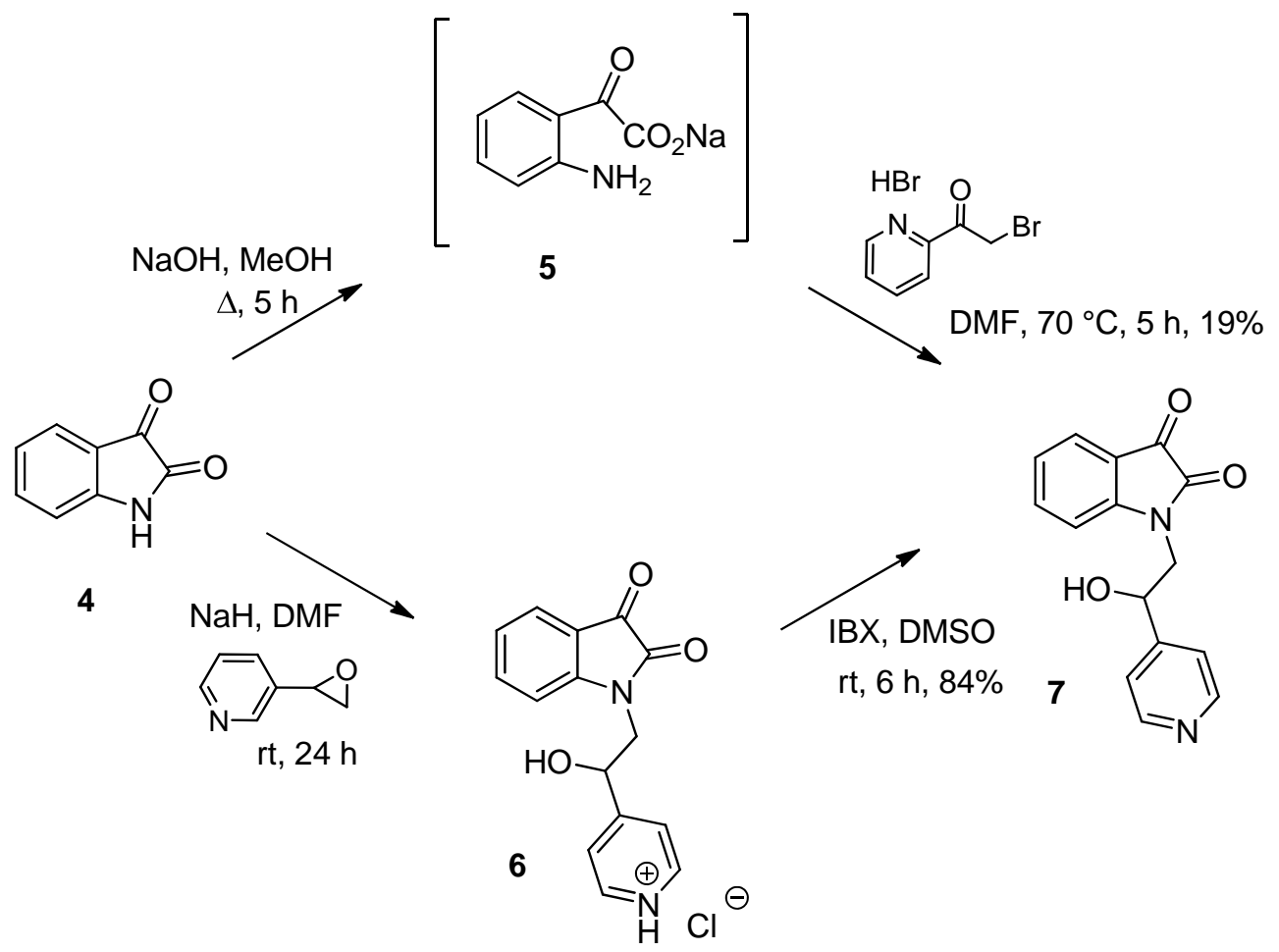

Scheme 2. Synthesis of 7.

The key intermediate 9 was subjected to esterification with ethanol to give corresponding ester $\mathbf{1 1}$ in $92 \%$ yield. The ortho-lithiation of $\mathbf{1 1}$ by utilizing of LiHMDS/TMEDA produced the target ellipticine quinone 12 in good yield (Scheme 4).

In 2014, Nagarajan et al. ${ }^{33}$ reported an expedient synthesis of the pyrido[4,3-b]carbazole alkaloids, ellipticine 29 and 9-methoxyellipticine $\mathbf{3 0}$ (Scheme 7) over seven steps from known 1,4-dimethylcarbazoles 13 
and 14 with $23 \%$ and $25 \%$ overall yields, respectively. For the first time, they have utilized the $\mathrm{H}_{3} \mathrm{PO}_{4}$-mediated Friedel-Crafts cyclodehydration as a key step to construct these pyrido[4,3-b]carbazole alkaloids.<smiles>O=C1C(=O)N(CC(O)c2ccncc2)c2ccccc21</smiles>

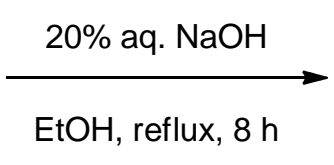<smiles>O=C(c1ccncc1)c1[nH]c2ccccc2c1C(=O)[O-]</smiles>

9<smiles>NC(=O)c1ccccc1NCCc1ccncc1</smiles>

8<smiles>O=C(c1ccncc1)c1cc2ccccc2[nH]1</smiles>

10

Scheme 3. Indoledione-indole rearrangement of $\mathbf{7}$ to carboxylic acid $\mathbf{9 .}$<smiles>O=C(c1ccncc1)c1[nH]c2ccccc2c1C(=O)[O-]</smiles>

9

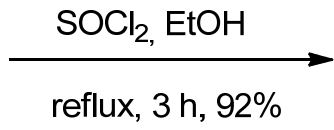

LiHMDS, TMEDA

$\mathrm{THF},-78^{\circ} \mathrm{C}$

$3 \mathrm{~h}, 68 \%$<smiles>O=C(c1ccncc1)c1[nH]c2ccccc2c1C(=O)O</smiles>

11<smiles>O=C1c2ccncc2C(=O)c2c1[nH]c1ccccc21</smiles>

12

Scheme 4. Synthesis of ellipticine quinone 12.

Their synthesis commenced with the preparation of 9-benzyl-1,4-dimethylcarbazoles $\mathbf{1 5}$ and $\mathbf{1 6}$ from the corresponding 1,4-dimethylcarbazoles, which can be readily prepared by literature methods (Scheme 5). NBenzylation of 13 and 14 afforded 15 and 16 in excellent yields. Next, Vilsmeier- Haack formylation of 15 and 16 with $\mathrm{DMF}$ and $\mathrm{POCl}_{3}$ at $70{ }^{\circ} \mathrm{C}$ furnished aldehydes 17 and 18. Subsequent Pinnick oxidation, using 30\% aqueous $\mathrm{H}_{2} \mathrm{O}_{2}, \mathrm{NaClO}_{2}$, and $\mathrm{KH}_{2} \mathrm{PO}_{4}$ in $\mathrm{THF}-\mathrm{H}_{2} \mathrm{O}(2: 1)$, transformed 17 and 18 into acids 19 and 20 in $94 \%$ and $97 \%$ yields, respectively. Acids 19 and 20 were converted into the corresponding acid chlorides using $\mathrm{SOCl}_{2}$, followed by amidation with 2-aminoethanol afforded the desired amides $\mathbf{2 1}$ and $\mathbf{2 2}$ along with esters $\mathbf{2 3}$ and 24 in smaller amounts (Scheme 5). 


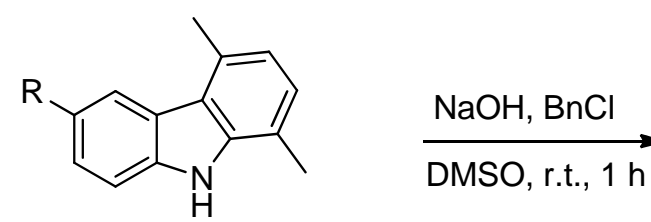

$13 \mathrm{R}=\mathrm{H}$

$14 \mathrm{R}=\mathrm{OMe}$<smiles>[R]c1ccc2[nH]c3c(C)cc(C=O)c(C)c3c2c1</smiles>

$17 \mathrm{R}=\mathrm{H} ; 71 \%$

$18 \mathrm{R}=\mathrm{OMe} ; 78 \%$

i) $\mathrm{SOCl}_{2}, \mathrm{CHCl}_{3}$

3-5 h, reflux

ii) DIPEA, $\mathrm{CH}_{2} \mathrm{Cl}_{2}$

$0{ }^{\circ} \mathrm{C}$ to r.t., $4-6 \mathrm{~h}$

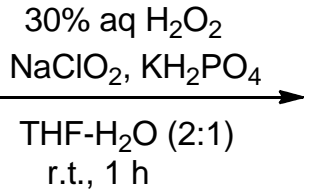

r.t., $1 \mathrm{~h}$

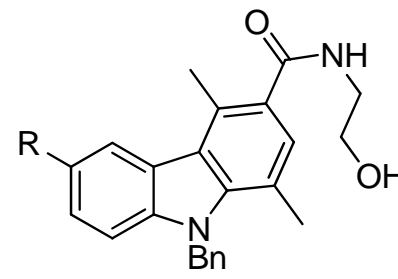

$21 \mathrm{R}=\mathrm{H} ; 86 \%$

$22 \mathrm{R}=\mathrm{OMe} ; 88 \%$<smiles></smiles>

$\underset{70^{\circ} \mathrm{C}, 2 \mathrm{~h}}{\stackrel{\mathrm{DMF}, \mathrm{POCl}_{3}}{\longrightarrow}}$

$15 \mathrm{R}=\mathrm{H} ; 84 \%$

$16 \mathrm{R}=\mathrm{OMe} ; 86 \%$
$19 \mathrm{R}=\mathrm{H} ; 94 \%$

$20 \mathrm{R}=\mathrm{OMe} ; 97 \%$

Scheme 5. Synthesis of 9-benzyl-N-(2-hydroxyethyl)-1,4-dimethyl-9H-carbazole-3-carboxamides 21 and 22.

Treatment of $\mathbf{2 1}$ or $\mathbf{2 2}$ with $\mathrm{H}_{3} \mathrm{PO}_{4}$ in air at $150{ }^{\circ} \mathrm{C}$ furnished dihydropyridocarbazolones $\mathbf{2 5}$ and $\mathbf{2 6}$ in $\mathbf{7 3 \%}$ and $71 \%$ yields, respectively. Under these rather forcing conditions, they also observed the formation of the oxidative cleavage products $\mathbf{1 5}$ or $\mathbf{1 6}$ in trace amounts (Scheme 6).<smiles>[R]c1ccc2[nH]c3c(C)cc(C(=O)NCCO)c(C)c3c2c1</smiles>

$21 \mathrm{R}=\mathrm{H}$

$22 \mathrm{R}=\mathrm{OMe}$

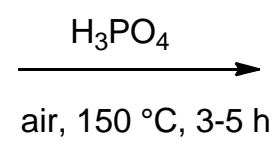

air, $150{ }^{\circ} \mathrm{C}, 3-5 \mathrm{~h}$

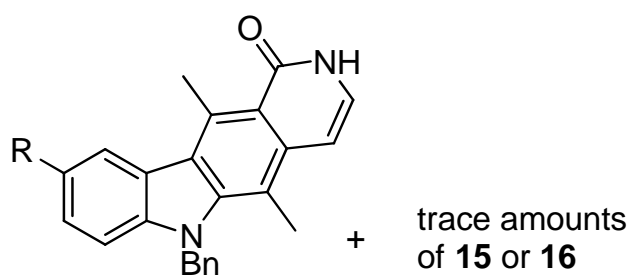

$25 \mathrm{R}=\mathrm{H} ; 73 \%$

$26 \mathrm{R}=\mathrm{OMe} ; 71 \%$

Scheme 6. The key $\mathrm{H}_{3} \mathrm{PO}_{4}$-mediated Friedel-Crafts cyclodehydration.

Having assembled the tetracyclic scaffold of the natural products, two simple transformations remained in order to access ellipticine $\mathbf{2 9}$ and 9-methoxyellipticine $\mathbf{3 0}$. This would involve conversion of the amide group 
into an imine followed by the cleavage of the $\mathrm{N}$-benzyl group in the intermediates $\mathbf{2 5}$ and $\mathbf{2 6}$. As shown in Scheme 7, the first of these challenges was achieved by reductive amination using mild reagents $\mathrm{Tf}_{2} \mathrm{O}$ and $\mathrm{Et}_{3} \mathrm{SiH}$. This generated $\mathrm{N}$-benzylellipticines $\mathbf{2 7}$ and $\mathbf{2 8}$ in good yields. Next, the N-benzyl group was removed from 27 and 28 by using $10 \%$ palladium on carbon to furnish ellipticines 29 and $\mathbf{3 0}$.<smiles>[R]c1ccc2[nH]c3c(C)c4cc[nH]c(=O)c4c(C)c3c2c1</smiles>

$25 \mathrm{R}=\mathrm{H}$

$26 \mathrm{R}=\mathrm{OMe}$

$\mathrm{H}_{2}, \mathrm{Pd} / \mathrm{C}, \mathrm{MeOH}$

reflux, $6 \mathrm{~h}$

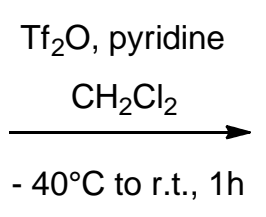

then

$\mathrm{Et}_{2} \mathrm{SiH}$, r.t., $5 \mathrm{~h}$<smiles>[R]c1ccc2[nH]c3c(C)c4ccncc4c(C)c3c2c1</smiles>

$27 \mathrm{R}=\mathrm{H} ; 87 \%$

$28 \mathrm{R}=\mathrm{OMe} ; 84 \%$<smiles>[R]c1ccc2[nH]c3c(C)c4ccncc4c(C)c3c2c1</smiles>

$29 \mathrm{R}=\mathrm{H} ; 75 \%$

$30 \mathrm{R}=\mathrm{OMe} ; 73 \%$

Scheme 7. Synthesis of ellipticine $\mathbf{2 9}$ and 9-methoxyellipticine $\mathbf{3 0 .}$

The same authors reported ${ }^{34}$ later a novel and concise total synthesis of biologically important ellipticine quinone and calothrixin B in three-step sequences of $67 \%$ and $38 \%$ good overall yields, respectively. They have also extended this route to the synthesis of olivacine in $16 \%$ overall yield over 6 steps. Their synthetic approach for these compounds is superior to that of previously reported methods in terms of availability of starting materials, overall yields, and the number of steps used.

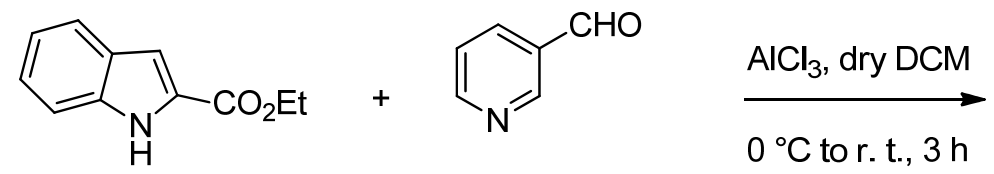

31<smiles>CCOC(=O)c1[nH]c2ccccc2c1C(O)c1cccnc1</smiles>

33 not isolated

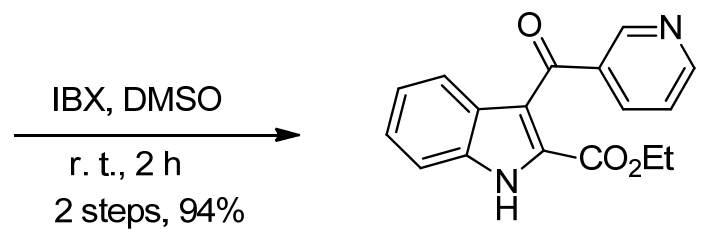

34

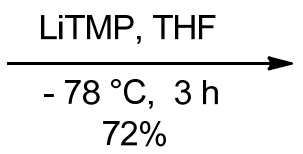

$72 \%$

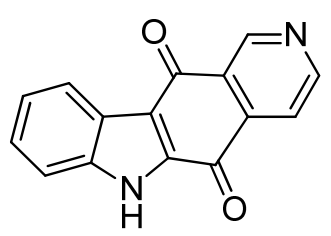

12

Scheme 8. Synthesis of ellipticine quinone. 
They treated commercially available ethyl $1 \mathrm{H}$-indole-2-carboxylate $\mathbf{3 1}$ with pyridine-3-carboxaldehyde 32 in presence of $\mathrm{AlCl}_{3}$ followed by oxidation using IBX in DMSO, giving ketone 34 in $94 \%$ yield. The carbinol formed $\mathbf{3 3}$ was not isolated from the reaction mixture, and subsequently they carried out oxidation after the reaction work up. The ketone $\mathbf{3 4}$ was then subjected to directed o-lithiation reaction using LiTMP (lithium tetramethylpiperidide) as a base to afford a single regioisomer 12 in 72\% yield. Thus, ellipticine quinone 12 was obtained in 3 steps and $67.6 \%$ overall yield (Scheme 8 ).

Similarly, isoellipticine quinones $\mathbf{3 9}$ and $\mathbf{4 0}$ can be obtained by varying pyridine part $\mathbf{3 6}$ as shown in Scheme 9. Also the other isomer of ellipticine quinone $\mathbf{4 3}$ was synthesized by using pyridine-2-carboxaldehyde 41.<smiles>[R]c1ccc2[nH]c(C(=O)OCC)cc2c1</smiles>

$31 \mathrm{R}^{2}=\mathrm{H}$

36

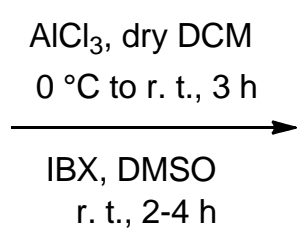

r. t., 2-4 h<smiles>[R]COC(=O)c1[nH]c2ccc([R])cc2c1C(=O)c1cccnc1</smiles>

$37 \mathrm{R}^{2}=\mathrm{H}, 92 \%$

$38 \mathrm{R}^{2}=\mathrm{OMe}, 95 \%$

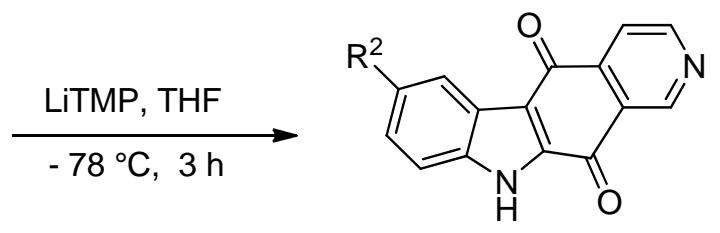

$39 \mathrm{R}^{2}=\mathrm{H}, 64 \%$

$40 \mathrm{R}^{2}=\mathrm{OMe}, 71 \%$<smiles>O=C(OF)c1cc2ccccc2[nH]1</smiles>

31

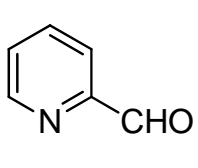

41

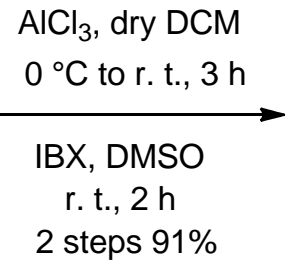

$\mathrm{AlCl}_{3}$, dry DCM

$\underset{\mathrm{IBX}, \mathrm{DMSO}}{\stackrel{0}{ }{ }^{\circ} \mathrm{C} \text { to r. t., } 3 \mathrm{~h}}$

r. t., 2 h
2 steps $91 \%$<smiles>CCOC(=O)c1[nH]c2ccccc2c1C(=O)c1ccccn1</smiles>

42

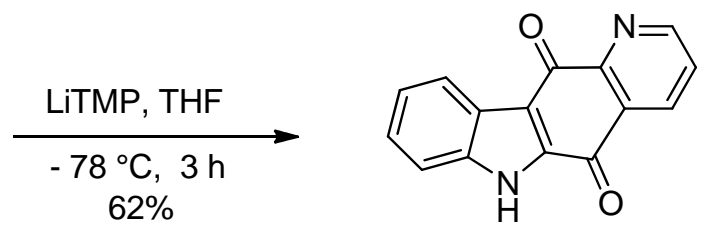

43

Scheme 9. Synthesis of isomeric ellipticine quinones. 
They have successfully applied their synthetic route to the synthesis of olivacine $\mathbf{4 8}$ and calothrixin B $\mathbf{5 1}$. Treatment of $\mathbf{3 1}$ with 2-methylnicotinaldehyde in the presence of 1,1,3,3-tetramethylguanidine (TMG) in $\mathrm{MeOH}$ at room temperature followed by oxidation using IBX afforded the ketone 45 in $84 \%$ yield. Wolff-Kishner reduction of the ketone $\mathbf{4 5}$ gave reduced compound $\mathbf{4 6}$. The cyclized compound $\mathbf{4 7}$ was obtained by treating 46 with LDA/HMPA at $-78{ }^{\circ} \mathrm{C}$. Finally, the addition of MeMgl into 47 followed by treatment upon $\mathrm{NaBH}_{4} / \mathrm{AlCl}_{3}(3: 1)$ in dry THF at room temperature produced 48 in $58 \%$ yield. Thus, olivacine 48 was obtained in 6 steps and $15.6 \%$ overall yield as shown in Scheme 10.<smiles>CCOC(=O)c1[nH]c2ccccc2c1C(c1cccnc1C)c1c(C(=O)OCC)[nH]c2ccccc12</smiles>

44

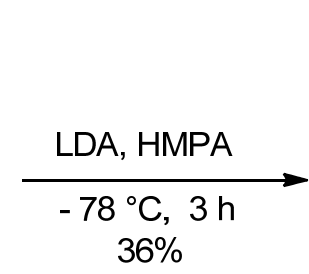

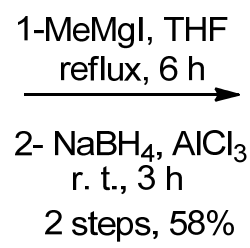

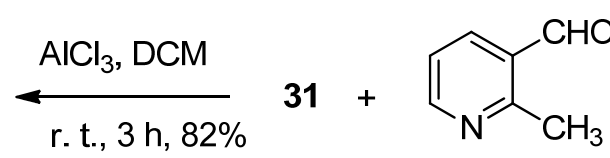<smiles>Cc1ncccc1Cc1c(C(=O)O)[nH]c2ccccc12</smiles>

46

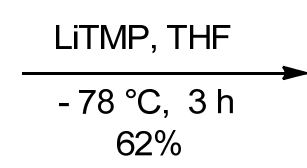

$62 \%$ $\underset{\text { 2- IBX, DMSO }}{\stackrel{\text { r.t., } 8 \mathrm{~h}}{\longrightarrow}}$

r. t., $4 \mathrm{~h}$ 2 steps, $84 \%$<smiles>CCOC(=O)c1[nH]c2ccccc2c1C(=O)c1cccnc1C</smiles>

45<smiles>Cc1nccc2c1Cc1c([nH]c3ccccc13)C2=O</smiles>

47

Scheme 10. Synthesis of olivacine $\mathbf{4 8}$

The synthesis of calothrixin B $\mathbf{5 0}$ is outlined in Scheme 11. The reaction of $\mathbf{3 1}$ with quinoline-3carboxaldehyde in the presence of TMG in $\mathrm{MeOH}$ followed by oxidation with Dess-Martin periodinane (DMP) in $\mathrm{DCM} / \mathrm{AcOH}$ (9:1) at room temperature gave the ketone 49 in $80 \%$ yield. Then intramolecular directed 0 lithiation reaction of $\mathbf{4 9}$ in the presence of LiTMP afforded $\mathbf{5 0}$ in $\mathbf{4 8 \%}$ yield. Thus, calothrixin B $\mathbf{5 0}$ was obtained in three steps and $38.4 \%$ overall yield.

In 2014, Konakahara et al. ${ }^{35}$ developed a simple and efficient synthetic method of novel four ellipticine derivatives in good to high yields. Moreover three kinds of novel pyridocarbazole-5-carboxylate derivatives were synthesized. All these new compounds exhibited higher solubility in water than ellipticine itself. 
<smiles>O=Cc1cnc2ccccc2c1</smiles>

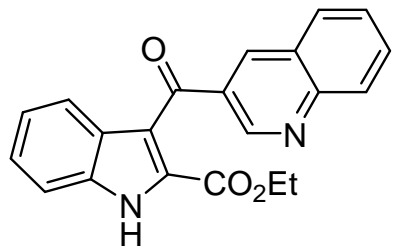

49

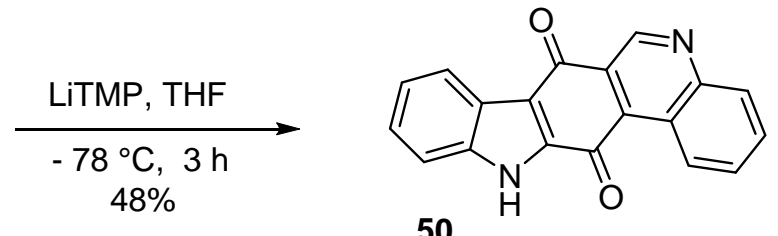

Scheme 11. Synthesis of Calothrixin B 50.

2-alkyl-5-methoxycarbonyl-11-methyl-6H-pyrido[4,3-b]carbazol-2-ium chloride derivatives were prepared from indole 51. First, the $\mathbf{N H}$ group of $\mathbf{5 1}$ was protected with benzensulfonyl group to give $\mathbf{5 2}$ which was oxalylated on the C-2 atom to give compound $\mathbf{5 3}$ in a $61 \%$ yield. Removal of benzene sulfonyl protecting group and hydrolysis of the ester group of $\mathbf{5 3}$ give the corresponding carboxylic acid $\mathbf{5 4}$ in an $\mathbf{8 5 \%}$ yield. The carbonyl group of $\mathbf{5 4}$ was reduced with hydrazine leading to the formation of 2 -indolylacetic acid $\mathbf{5 5}$. The crude product was treated with trimethylsilyldiazomethane to give the corresponding methyl ester 56. Finally, a mixture of 56 and 3-acetylpyridine was heated in the presence of concentrated sulfuric acid leading to methyl 2-(3-(1(pyridin-yl)vinyl)- $1 \mathrm{H}$-indol-2-yl)acetate $\mathbf{5 7}$ in 65\% yield (Scheme 12 ).

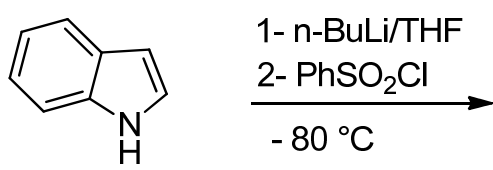

51

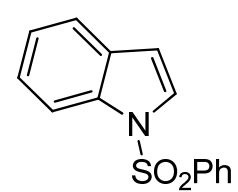

52, $85 \%$

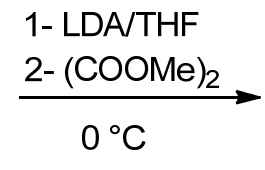<smiles>O=C(O)Cc1cc2ccccc2[nH]1</smiles>

55<smiles>COC(=O)C(=O)c1cc2ccccc2n1-c1ccccc1</smiles>

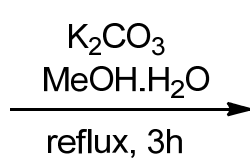<smiles>COC(=O)Cc1cc2ccccc2[nH]1</smiles>

56, $75 \%$ from 53<smiles>O=C(O)C(=O)c1cc2ccccc2[nH]1</smiles>

54, $85 \%$

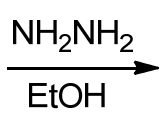

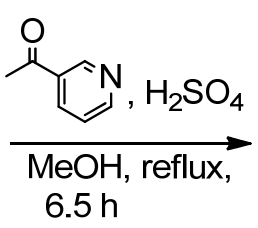

$6.5 \mathrm{~h}$<smiles>C=C(c1cccnc1)c1c(CC(=O)OC)[nH]c2ccccc12</smiles>

57, $65 \%$

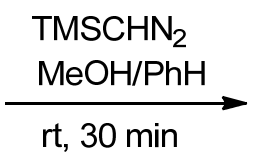

$\mathrm{rt}, 30 \mathrm{~min}$

Scheme 12. Synthesis of 57. 
To construct a pyridocarbazole ring, the compound $\mathbf{5 7}$ was treated with $\mathbf{5 8}$ and $\mathbf{5 9}$ in the presence of 3ethoxycarbonyl-1-methylpyridinium chloride 62 leading to 2-alkylpyridocarbazolium derivatives $64 a, \mathbf{b}$ in a yield of $10 \%$ (Scheme 13). Alternatively, the 2-alkylpyridocarbazolium derivatives 64a, 64b and 64d were prepared in good yields in two steps via treatment of 57 with $\mathbf{6 1 a}, \mathbf{6 1 b}$ and $\mathbf{6 1 d}$ respectively, in the presence of NaOMe and $\mathbf{6 2}$ followed by the action of Amberlite IRA-900 (Scheme 13). The stability of the quaternary salts of these molecules increases by converting them into the corresponding tosylate and chloride salts.

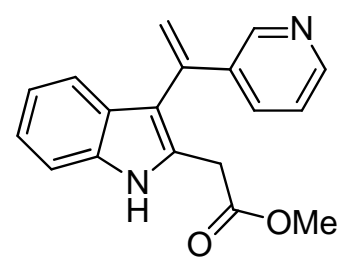

57, $65 \%$
1- 58, 59, 60

DMF, $110^{\circ} \mathrm{C}, 15 \mathrm{~h}$

2- $\mathrm{NaOMe}, \mathrm{MeOH}, \mathrm{rt}, 1$

3-

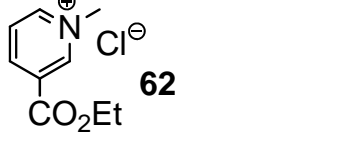

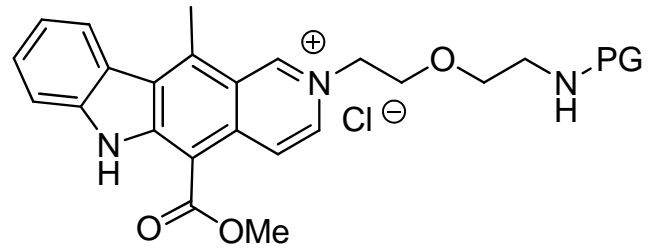

64a-d

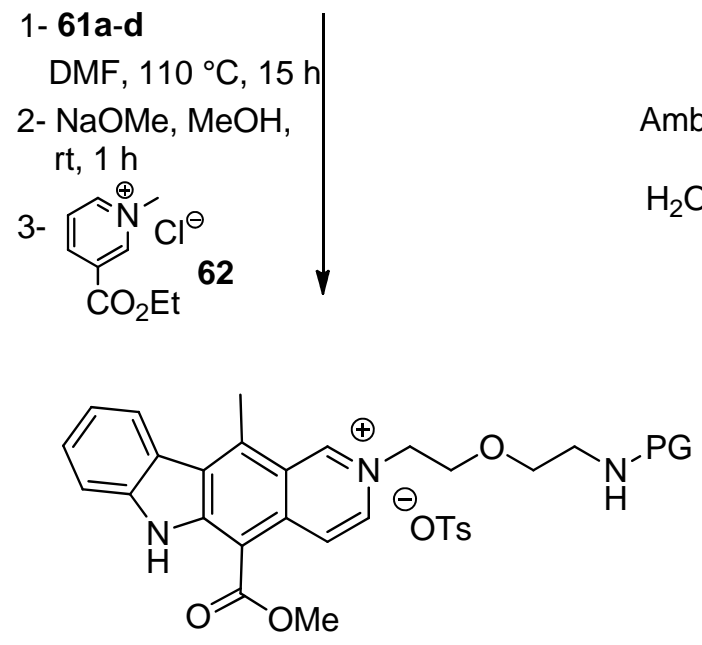

63a-d
Amberlite IRA-900

$\mathrm{H}_{2} \mathrm{O}, \mathrm{rt}, 5 \mathrm{~h}$

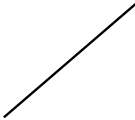

$\mathrm{HCl}$<smiles>O=C1c2ccccc2C(=O)N1CCOCCCl</smiles><smiles>ClCCOCCN[Pb]</smiles>

59: $P G=A c$

60: NHPG = dimethylpyrrolyl<smiles>[AsH2]NCCOCCO[AsH3]</smiles>

61a: $N H P G=P h t$

61b: $P G=A c$

61c: $\mathrm{NHPG}=$ dimethylpyrrolyl

61d: $\mathrm{NHPG}=\mathrm{Boc}$

Scheme 13. Synthesis of 2-alkylellipticinium analogue 65.

Ellipticine 29, hydroxyellipticine 70, 6-methylellipticine 67 and 9-hydroxy-6-methylellipticine 69 were prepared via a modification of a previously reported method, ${ }^{36}$ as shown in Scheme 14 for 67 and 69 and followed by Dakin oxidation leading to the formation of 9-hydroxyellipticine $\mathbf{7 0}$ in $55 \%$ yield. 

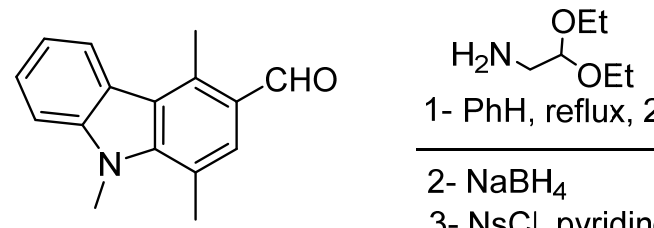

1- $\mathrm{PhH}$, reflux, $2 \mathrm{~h}$

2- $\mathrm{NaBH}_{4}$

3- $\mathrm{NsCl}$, pyridine, $\mathrm{MeCN}$

$\mathrm{rt}, 6 \mathrm{~h}$

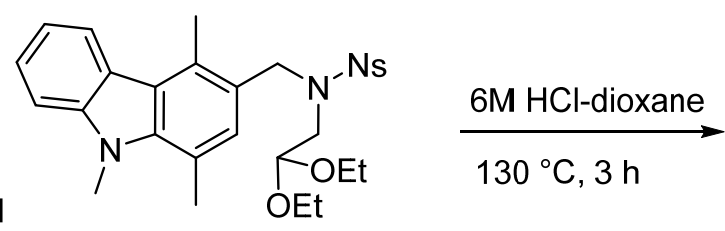

66, $54 \%$
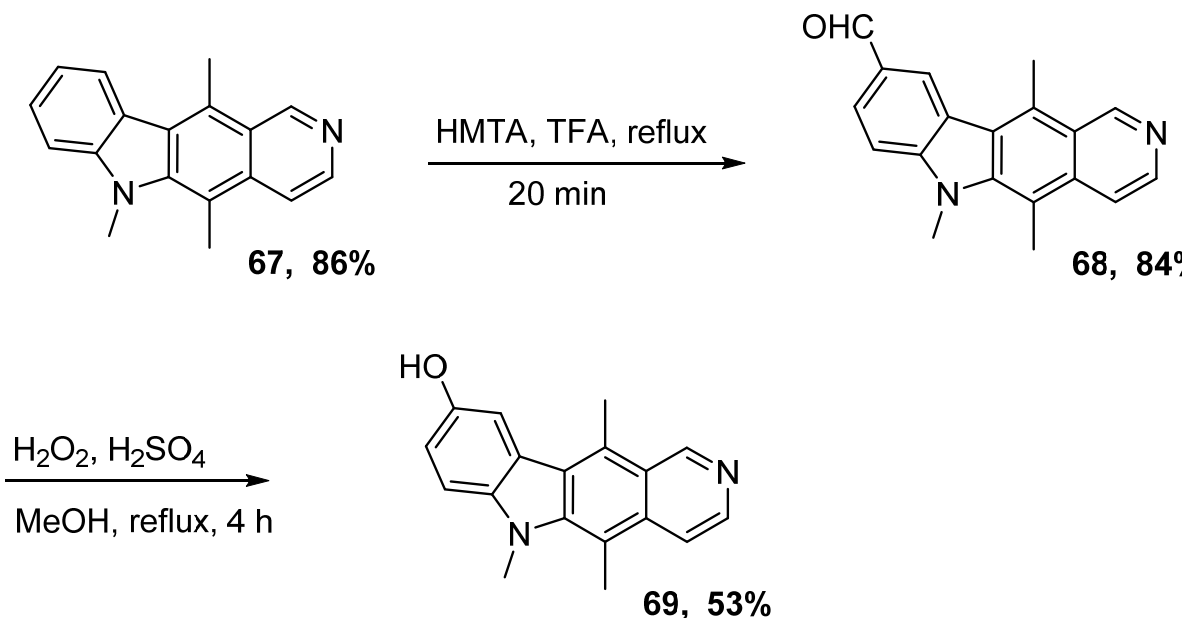

Scheme 14. Synthesis of 6-methylellipticine 67 and 9-hydroxy-6-methylellipticine 69.<smiles>[R]c1ccc2c(c1)c1c(C)c3cnccc3c(C)c1n2[R1]</smiles>

$29: \mathrm{R}=\mathrm{H}, \mathrm{R}^{1}=\mathrm{H}$

$70: \mathrm{R}=\mathrm{OH}, \mathrm{R}^{1}=\mathrm{H}$

$69: \mathrm{R}=\mathrm{OH}, \mathrm{R}^{1}=\mathrm{CH}_{3}$

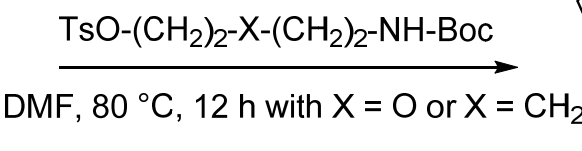

DMF, $80^{\circ} \mathrm{C}, 12 \mathrm{~h}$ with $\mathrm{X}=\mathrm{O}$ or $\mathrm{X}=\mathrm{CH}_{2}$

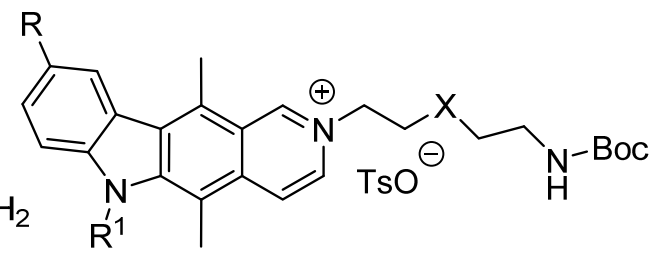

71a : $\mathrm{R}=\mathrm{H}, \mathrm{R}^{1}=\mathrm{H}, \mathrm{X}=\mathrm{O}$

71b: $\mathrm{R}=\mathrm{OH}, \mathrm{R}^{1}=\mathrm{H}, \mathrm{X}=\mathrm{O}$

71c: $\mathrm{R}=\mathrm{OH}, \mathrm{R}^{1}=\mathrm{CH}_{3}, \mathrm{X}=\mathrm{O}$

71d: $\mathrm{R}=\mathrm{OH}, \mathrm{R}^{1}=\mathrm{CH}_{3}, \mathrm{X}=\mathrm{CH}_{2}$

\section{Amberlite IRA-900}

$\mathrm{H}_{2} \mathrm{O}, \mathrm{rt}, 5 \mathrm{~h}$<smiles>[R]c1ccc(F)cc1</smiles>

72a $: \mathrm{R}=\mathrm{H}, \mathrm{R}^{1}=\mathrm{H}, \mathrm{X}=\mathrm{O} ; 52 \%$

72b : $\mathrm{R}=\mathrm{OH}, \mathrm{R}^{1}=\mathrm{H}, \mathrm{X}=\mathrm{O} ; 52 \%$

72c : $\mathrm{R}=\mathrm{OH}, \mathrm{R}^{1}=\mathrm{CH}_{3}, \mathrm{X}=\mathrm{O} ; 52 \%$

72d: $\mathrm{R}=\mathrm{OH}, \mathrm{R}^{1}=\mathrm{CH}_{3}, \mathrm{X}=\mathrm{CH}_{2} ; 50 \%$

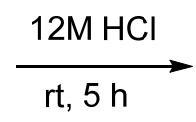

$\mathrm{R}$<smiles>CC(C)(C)O[Pb]NCCCCl</smiles>$$
\mathrm{r}, 5 \mathrm{~h}
$$<smiles></smiles>

73a : $\mathrm{R}=\mathrm{H}, \mathrm{R}^{1}=\mathrm{H}, \mathrm{X}=\mathrm{O} ; 86 \%$

73b : $\mathrm{R}=\mathrm{OH}, \mathrm{R}^{1}=\mathrm{H}, \mathrm{X}=\mathrm{O} ; 85 \%$

73c: $\mathrm{R}=\mathrm{OH}, \mathrm{R}^{1}=\mathrm{CH}_{3}, \mathrm{X}=\mathrm{O} ; 86 \%$

73d : $\mathrm{R}=\mathrm{OH}, \mathrm{R}^{1}=\mathrm{CH}_{3}, \mathrm{X}=\mathrm{CH}_{2} ; 82 \%$

Scheme 15. Synthesis of 2-alkyl analogues of ellipticine 73a-d. 
Ellipticine 29, 9-hydroxyellipticine 70, and 9-hydroxy-6-methylellipticine 69 were treated with $\mathbf{6 1 d}$ to form the corresponding ellipticinium tosylate quaternary salts 71a-c (Scheme 15). In a similar manner, tosylate salts 71a-d were then treated with Amberlite IRA-900 to give the corresponding chloride salts 72a-d. These chloride salts were then refluxed in $\mathrm{HCl}(12 \mathrm{M})$ to give the 2-alkyellipticinium analogues 73a-d in good yields.

The obtained 2-(2-aminoethoxy)ethoxy)ethyl-5-methoxycarbonyl-11-methyl-6H-[4,3-b]carbazol-2-ium chloride 65 and its analogues 73a-d were treated with $p$-nitrophenyl $N$-methylcarbamate 74a and its $N$-nitroso derivative $\mathbf{7 4 b}$ to get the corresponding urea derivatives 75a-e and $N$-nitrosourea derivatives 76a-e (Scheme 16).

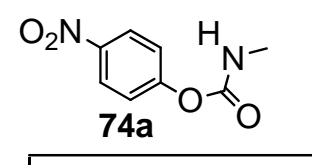

DIEA, DMF, $0{ }^{\circ} \mathrm{C}, 7 \mathrm{~h}$
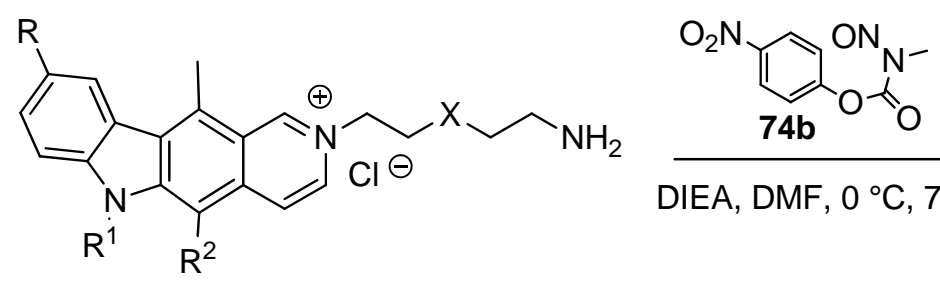

DIEA, DMF, $0{ }^{\circ} \mathrm{C}, 7 \mathrm{~h}$

65, 73a-d

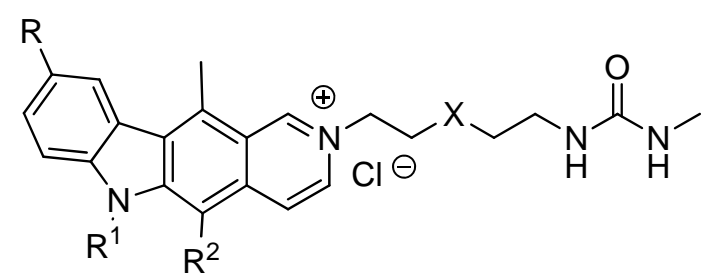

75a-d; $43-74 \%$

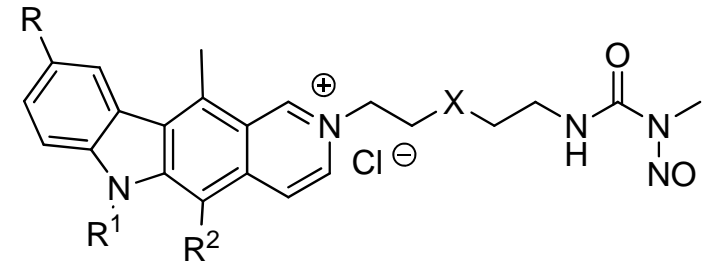

76a-d; $20-64 \%$

Scheme 16. Synthesis of urea and nitrosourea analogues of ellipticine derivatives 75a-e, 76a-e.

Finally, 2-(2-aminoethyl)- and 2-(3-aminopropyl)-pyridocarbazol-2-ium chlorides 81-88 were synthesized by a method analogous to the synthesis of 75e and 76e in poor to high yields (Scheme 17).

In 2016, Ergün et al. $^{37}$ reported a new synthetic route for the synthesis of 5-methyl-6H-pyrido[4,3b]carbazole 96 , so called 11-demethylellipticine (Scheme 18). They have used tetrahydrocarbazole acid 89 as a starting material and synthesized according to the literature. ${ }^{38}$ Then, acid $\mathbf{8 9}$ was converted to glycine $\mathbf{9 0}$ derivative using ethyl chloroformate and methyl glycinate. The reduction of glycine $\mathbf{9 0}$ with lithium aluminium hydride gave amine alcohol 91. Amine alcohol 91 was reacted with benzene sulfonyl chloride and gave protected compound 92. The oxidation of the compound 92 at position 1 with periodic acid yielded tetrahydrocarbazolone $\mathbf{9 3}$. Then, reaction of 93 in the presence of sodium hydride led to the tetracyclic structure 94. Finally, pyridocarbazole 96 was synthesized by aromatization of compound 95, which was obtained from reaction between compound $\mathbf{9 4}$ and methyl lithium. One of the syntheses of pyridocarbazole alkaloid olivacine had been achieved via the reaction between pyridocarbazole $\mathbf{9 6}$ and methyl lithium in the literature previously. ${ }^{39}$ Tetracyclic structure 94 can also allow the synthesis of several ellipticine derivatives. 
<smiles>[R]n1c(CC(=O)OC)c(C(=C)c2cccnc2)c2ccccc21</smiles>

77
1- 78a/DMF, $110^{\circ} \mathrm{C}, 15 \mathrm{~h}$

$78 \mathrm{~b} / \mathrm{CH}_{3} \mathrm{CN}$, reflux, $72 \mathrm{~h}$ 2- $\mathrm{NaOMe}, \mathrm{MeOH}, \mathrm{rt}, 1 \mathrm{~h}$

3-

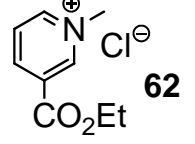

$\mathrm{MeOH}, \mathrm{rt}, 5 \mathrm{~h}$

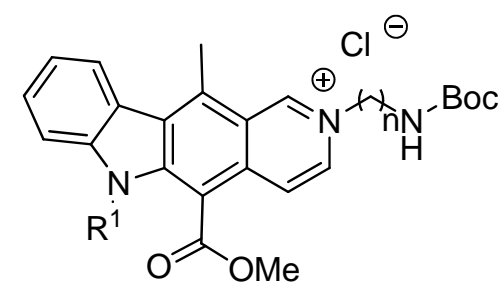

$79: n=2 ; 21 \%$

$80: n=3 ; 25 \%$

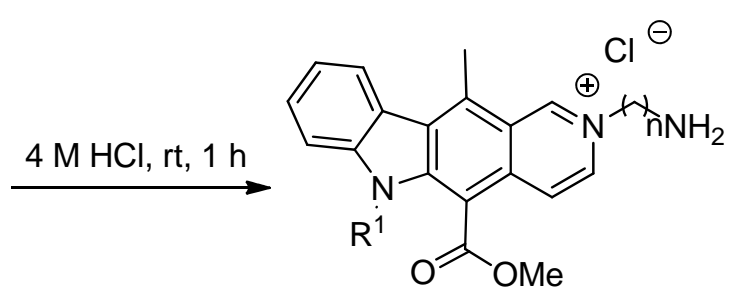

81: $n=2 ; 97 \%$

$82: n=3 ; 95 \%$

Cl $\chi_{\mathrm{n}} \mathrm{NH}_{2} \cdot \mathrm{HCl}$
$\underset{\mathrm{CHCl}_{3}, \text { reflux, } 1 \mathrm{~h}}{\stackrel{\mathrm{Boc}_{2} \mathrm{O}, \mathrm{Et}_{3} \mathrm{~N}}{\longrightarrow}}$

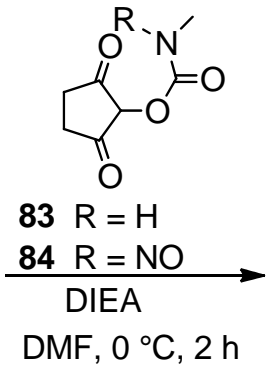

DMF, $0^{\circ} \mathrm{C}, 2 \mathrm{~h}$

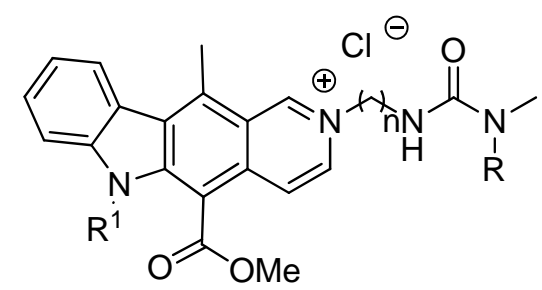

85: $n=2, R=H ; 78 \%$
86: $n=2, R=N O ; 76 \%$
87: $n=3, R=H ; 79 \%$
88: $n=3, R=N O ; 76 \%$

${ }_{\mathrm{Cl}} \mathrm{NH}_{\mathrm{n}}^{-\mathrm{BOC}}$

78a : $n=2 ; 95 \%$

78b : $n=3 ; 93 \%$

Scheme 17. Synthesis of urea and nitrosourea derivatives of pyridocarbazole-5-carboxylates 85-88. 
<smiles>O=C(O)C1CCc2[nH]c3ccccc3c2C1</smiles>

89

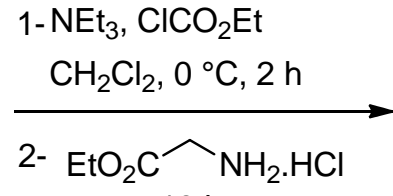

$18 \mathrm{~h}$<smiles>OCCNCC1CCc2[nH]c3ccccc3c2C1</smiles>

91

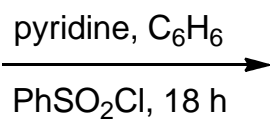

$\mathrm{PhSO}_{2} \mathrm{Cl}, 18 \mathrm{~h}$<smiles>COC(=O)CNC(=O)C1CCc2[nH]c3ccccc3c2C1</smiles>

90<smiles>CO[Sb](=O)(O)(O)CCNCC1CCc2[nH]c3ccccc3c2C1</smiles>

92<smiles>O=C1CC(CNCCOS(=O)(=O)c2ccccc2)Cc2c1[nH]c1ccccc21</smiles>

93

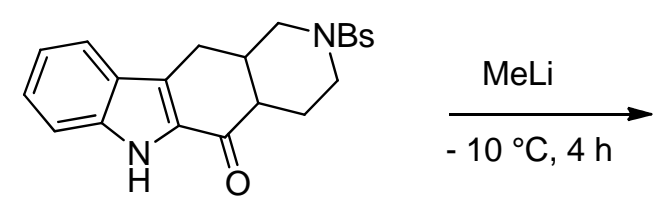

94<smiles>CC1(O)c2[nH]c3ccccc3c2CC2CNCCC21</smiles>

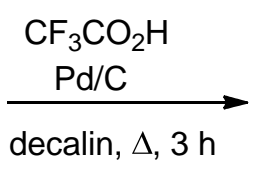<smiles>Cc1c2ccncc2cc2c1[nH]c1ccccc12</smiles>

96<smiles>Cc1nccc2c(C)c3[nH]c4ccccc4c3cc12</smiles>

Olivacine

Scheme 18. Synthesis of 11-demethylellipticine 96.

The same year Konakahara and al. $^{40}$ succeeded in developing the simple and efficient synthesis of three novel 9-hydroxyellipticine derivatives linked with a glucose moiety by a triazole ring-succinate tether at the position 9 of an ellipticine nucleus (Scheme 19).

9-Hydroxysuccinate 97 was synthesized by a previously reported method, ${ }^{41}$ and then treated with monopropargyl succinate $\mathbf{9 8}$ leading to the formation of ellipticin-9-yl propargyl succinate $\mathbf{9 9}$ in a $78 \%$ yield.<smiles>C#CCOC(=O)CCC(=O)OCC(=O)Oc1ccc2[nH]c3c(C)c4ccncc4c(C)c3c2c1</smiles>

Scheme 19. Synthesis of ellipticin-9-yl propargyl succinate 99. 
Reaction of ellipticin-9-yl propargyl succinate 99 and 2-azidoethyl $\beta$-D-glucopyranoside 100a was performed and the best yields were obtained using Cul as catalyst in the presence of diisopropylethylamine (DIPEA) (Scheme 20).<smiles>C#CCOC(=O)CCC(=O)Oc1ccc2[nH]c3c(C)c4ccncc4c(C)c3c2c1</smiles><smiles>Cc1c2ccncc2c(C)c2c1[nH]c1ccc(OC(=O)CCC(=O)OCc3cn(CCOC4OC(O)C(O)C(O)C(O)C4O)nn3)cc12</smiles>

Scheme 20. Huisgen reaction of 2-azidoethyl $\beta$-D-glucopyranoside $100 a$ and ellipticin-9-yl propargyl succinate 99.

The reaction of 99 with $\beta$-D-glucopyranosyl azide 100b and 2-acetamido-2-deoxy- $\beta$-D-glucopyranosyl azide 100c gave the corresponding products 101b-c, in 94 and $90 \%$ yields, respectively (Scheme 21).

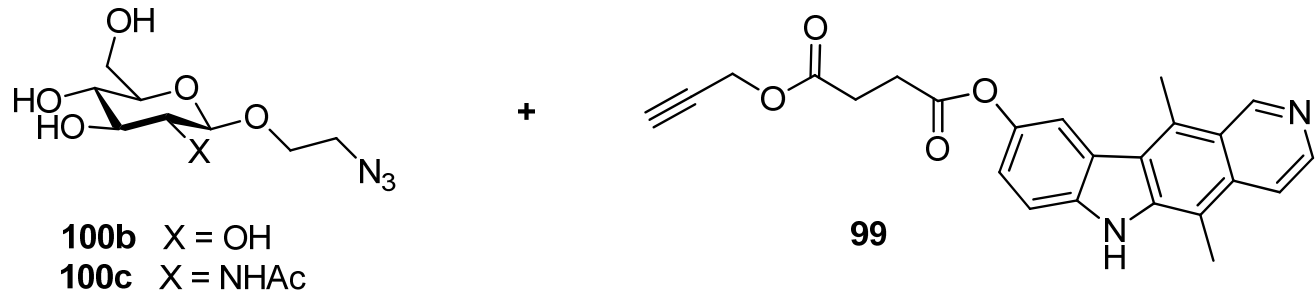

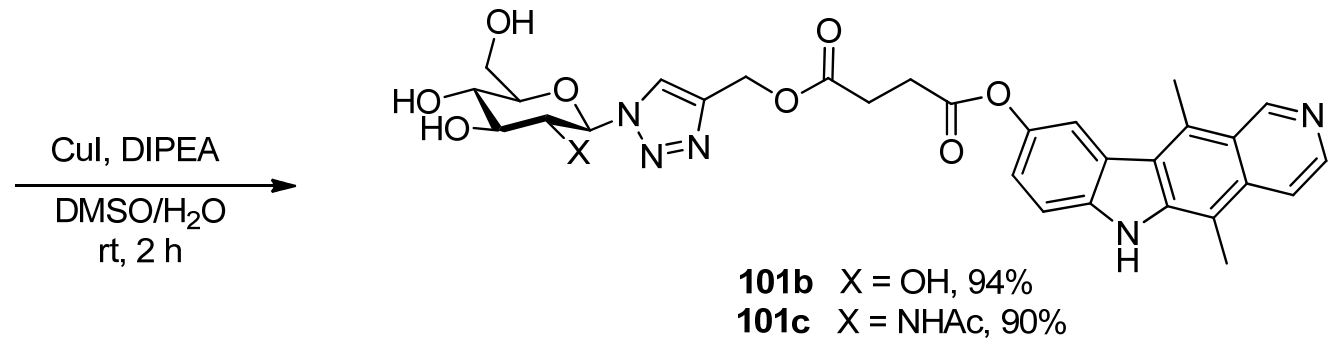

Scheme 21. Huisgen reaction of 2-azidoethyl $\beta$-D-glucopyranoside 101b-c and ellipticin-9-yl propargyl succinate 100.

These compounds exhibited potent antitumor activity. The introduction of glucose conjugaison at the 9position enhanced its solubility in water compared with those of ellipticine alone. This is the first report of the synthesis and evaluation of the antitumor activity of the uncharged glucose-conjugates of 9-hydroxyellipticine with increased water solubility. 
An efficient and simple Ni-catalyzed C(aryl)-OMe bond cleavage and subsequent C(aryl)-Me bond formation by treating carbazoles with MeMgBr has been developed in 2016 by Das et al. ${ }^{42}$ This protocol was successfully applied to the synthesis of the natural product ellipticine from readily available starting materials.<smiles>COc1ccc(OC)c(C=O)c1</smiles>

102
1- $\mathrm{CuSO}_{4} \cdot 6 \mathrm{H}_{2} \mathrm{O}$ $\mathrm{Ac}_{2} \mathrm{O}, \mathrm{rt}, 24 \mathrm{~h}$

2- $\mathrm{HNO}_{3}, 0^{\circ} \mathrm{C}, 1 \mathrm{~h}$

3- $1 \mathrm{~N} \mathrm{HCl}, \mathrm{rt}, 2 \mathrm{~h}$

$80 \%$<smiles>COc1cc(C=O)c([N+](=O)[O-])cc1OC</smiles>

103<smiles>CCOC(CN)OCCCCOC(C)C</smiles>

$\mathrm{C}_{6} \mathrm{H}_{6}, \Delta, 6 \mathrm{~h}$<smiles>CCOC(C/N=C\c1cc(OC)c([N+](=O)[O-])cc1OC)OCC</smiles>

104

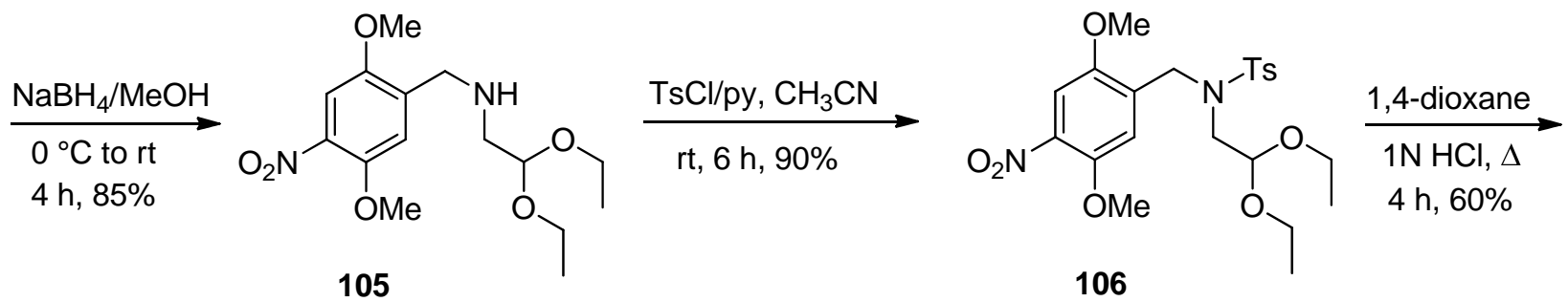<smiles>COc1cc([N+](=O)[O-])c(OC)c2ccncc12</smiles>

107

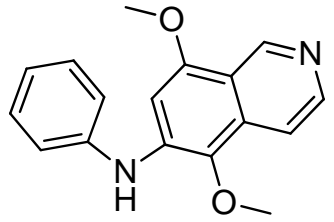

110

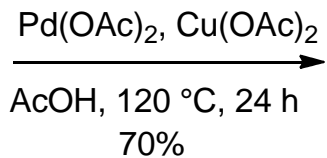

$70 \%$<smiles>COc1cc(N)c(OC)c2cnccc12</smiles>

108

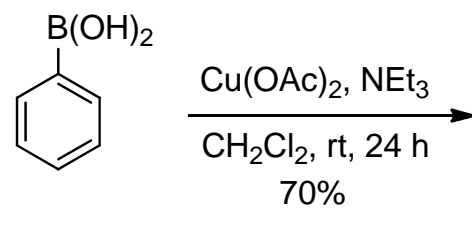

109

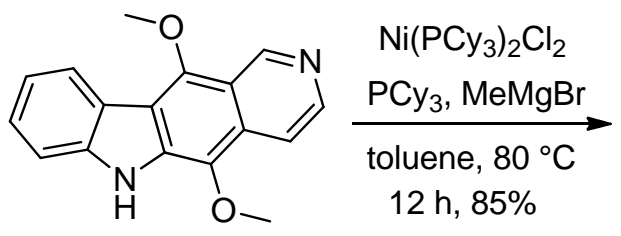

111<smiles>Cc1c2cnccc2c(C)c2c1[nH]c1ccccc12</smiles>

Ellipticine

Scheme 22. Total synthesis of ellipticine.

They used commercially available 2,5-dimethoxybenzaldehyde 102 as the starting material and introduced the methyl group through a Ni-catalyzed Kumada-type coupling reactions at a late stage of the synthesis. They began the synthesis with the nitration reaction $\left(\mathrm{CuSO}_{4} \cdot 6 \mathrm{H}_{2} \mathrm{O} / \mathrm{HNO}_{3}\right)$ of 2,5-dimethoxybenzaldehyde 102 to afford nitration product 103 in 80\% yield (Scheme 22). The condensation reaction of 103 with aminoacetaldehydediethyl acetal in dry benzene gave imine product 104 . The subsequent reduction of 104 with sodiumborohydride in methanol afforded amine 105 in 85\% yield. The protection of amine 105 with a tosyl group gave protected compound 106, which underwent cyclization in an acidic medium to furnish isoquinoline 107 in 54\% yield (two steps). In the next step, the reduction of the nitro group was achieved by using $\mathrm{Pd} / \mathrm{C}$ in methanol, and amine 108 was isolated in $80 \%$ yield. This product was then subjected to a Cu- 
catalyzed Chan-Lam-type coupling with phenylboronic acid 109 to afford $\mathrm{N}$-arylated product $110 .^{43}$ Subsequently, the preparation of carbazole 111 was achieved in $70 \%$ yield by using a Pd-catalyzed crossdehydrogenative $(C D C)$ coupling reaction. Finally, they applied their optimized Ni-catalyzed protocol to replace the methoxy with a methyl group to afford ellipticine in $85 \%$ yield.

This protocol demonstrates that the lipophilicity of bioactive carbazoles can be easily modified by replacing a methoxy with a methyl group, which is important in the regulation of drug properties such as bioavailability and metabolic stability.

Topcu et al. ${ }^{44}$ synthesized in 2016 two novel ellipticine derivatives, $N$-methyl-5-demethyl ellipticine (ET-1) and 2-methyl-N-methyl-5-demethyl ellipticinium iodide (ET-2), via a novel pathway shown in Scheme 23.

ET-1 and ET-2 were generated using a nine-step synthetic pathway with a $12 \%$ overall yield. First, 4,9dimethyl-9H-carbazole-3-carbaldehyde $112^{45}$ was treated with aminoacetaldehyde diethylacetal to yield imine 113. The imine was reduced with sodium borohydride to produce amine 114, which was treated with benzene sulfonyl chloride to produce sulfonamide 115. Finally, cyclization of ET-1 was achieved by treating sulfonamide $\mathbf{1 1 5}$ with hydrochloric acid. ET-2 was obtained by treating ET-1 with iodomethane in DMF. ET-1 and ET-2 were more soluble than ellipticine.<smiles>Cc1c(C=O)ccc2c1c1ccccc1n2C</smiles>

112

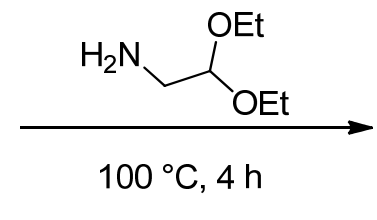

$100{ }^{\circ} \mathrm{C}, 4 \mathrm{~h}$<smiles>CCOC(C/N=C\c1ccc2c(c1C)c1ccccc1n2C)OCC</smiles>

113

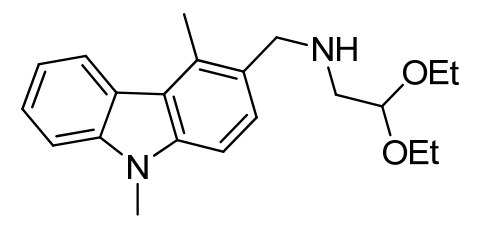

114

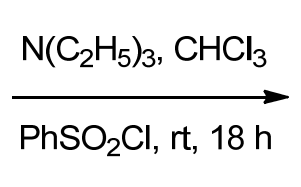

$\mathrm{PhSO}_{2} \mathrm{Cl}, \mathrm{rt}, 18 \mathrm{~h}$

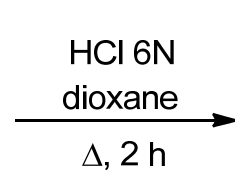

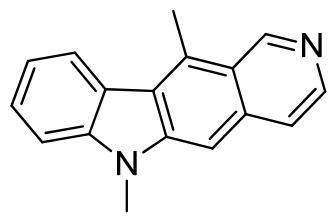

ET-1

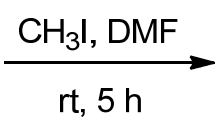

rt, $5 \mathrm{~h}$

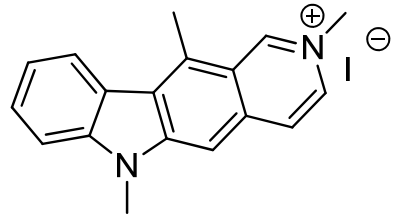

ET-2

Scheme 23. Synthetic pathway of novel ellipticine derivatives.

A series of 3-(alkyl)(dialkyl)amino)benzofuro[2,3-f]quinazolin-1(2H)-ones 119 has been synthesized as new ellipticine analogs by Ando and al. ${ }^{46}$ in 2016.

3-Aminodibenzofurans 116a-b were used as starting materials (Scheme 24). The amino derivatives 116a-b were reacted with ethoxycarbonylisothiocyanate to give the thiourea intermediates $\mathbf{1 1 7}$, followed by the addition of the appropriate alkylamine or dialkylamine and $\mathrm{HgCl}_{2}$ to give the ethoxycarbonylguanidine 
intermediates 118. The latter intermediates were subjected to thermal cyclization followed by filtration of the HgS-by-product to give the 3-(alkyl)(dialkyl)amino)benzofuro[2,3-f]quinazolin-1(2H)-ones 119, respectively.

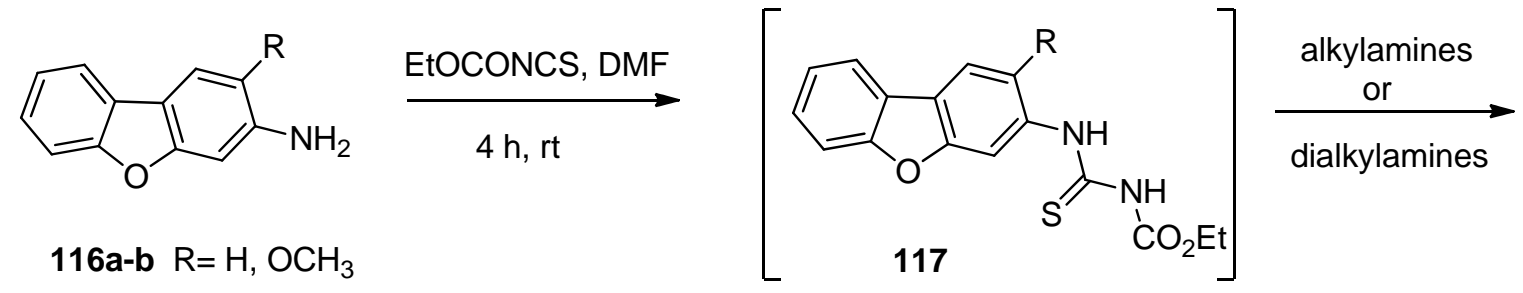

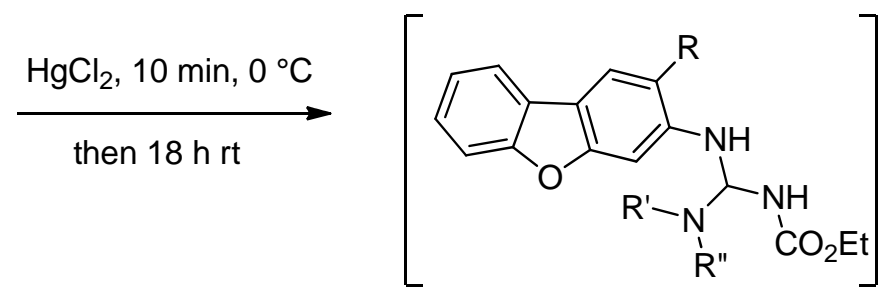

118

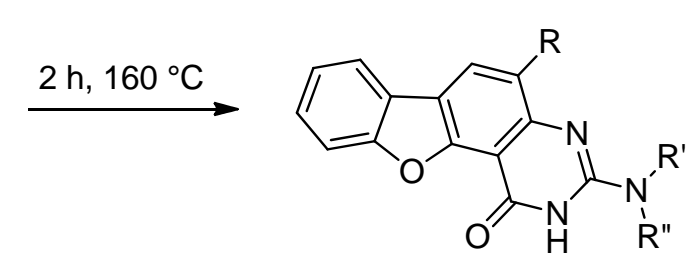

11913 examples

Scheme 24. Synthesis of 3-(alkyl)(dialkyl)amino)benzofuro[2,3-f]quinazolin-1(2H)-ones 119.

Ishikura et al. ${ }^{47}$ reported the total syntheses of 9-methoxyellipticine $30,3,4$-dihydroellipticine $128,1,2,3,4-$ tetrahydroellipticine 129, 2-methyl1,2,3,4-tetrahydroellipticine 131, olivacine 142, 3,4-dihydroolivacine 141, $( \pm)$-janetine 138, and ( \pm )-guatambuine 136 using triene 120 as a key intermediate. The cyclization of triene 120 to pyridocarbazole $\mathbf{1 2 2}$ was successfully performed by taking advantage of Cu-mediated 6r-electrocyclization, enabling a gram-scale reaction (Scheme25).

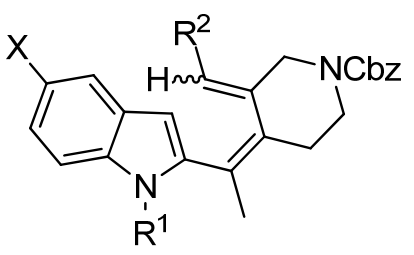

120

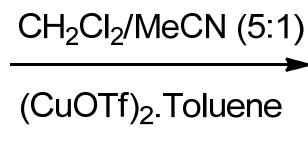

$(\mathrm{CuOTf})_{2}$-Toluene

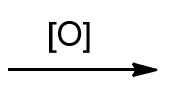

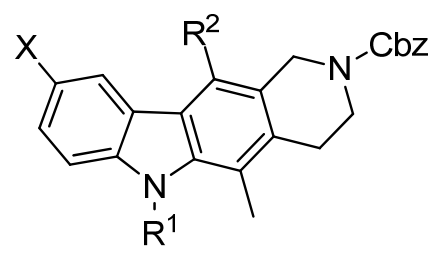

122

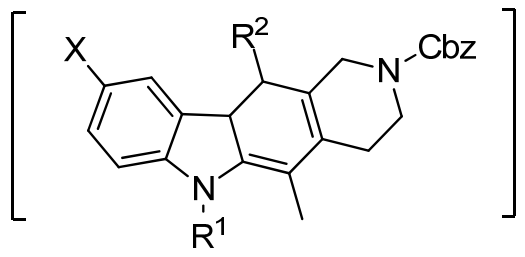

121

$$
\begin{aligned}
& R^{1}=\text { Boc, Me or OMe } \\
& R^{2}=\text { Me or } H \\
& X=H \text { or OMe } \\
& \text { Yield: } 60 \% \text { to } 80 \%
\end{aligned}
$$

Scheme 25. Cu-mediated cyclization of indole 120.

9-methoxyellipticine $\mathbf{3 0}$ was synthesized starting from carbazole $\mathbf{1 2 2 b}$ (Scheme 26). The $\mathrm{N}$-Cbz group was removed by catalytic hydrogenation, and resulting amine 123 was subjected, without further purification, to oxidation with $\mathrm{MnO}_{2}$ in dioxane at $100{ }^{\circ} \mathrm{C}$, to afford 124 in $70 \%$ yield. Removal of the $\mathrm{N}$-Boc group with $\mathrm{BBr}_{3}$ afforded 30 in $75 \%$ yield. 


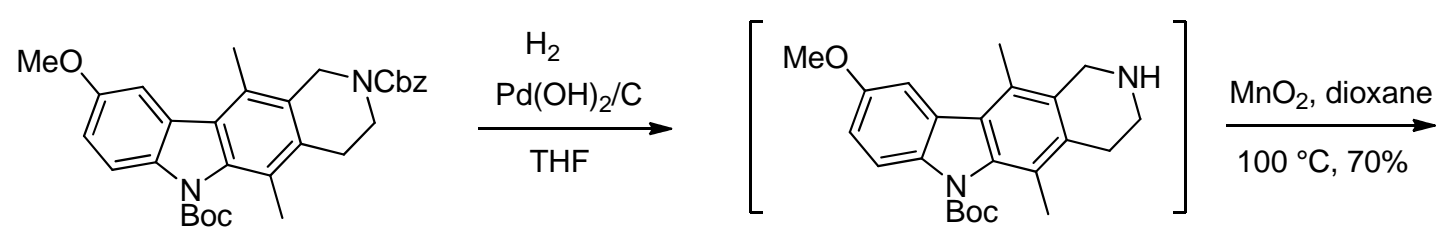

$122 b$

123

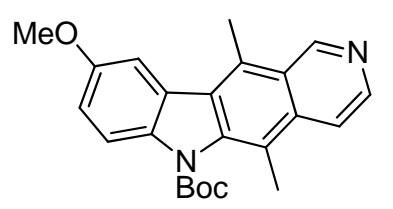

124

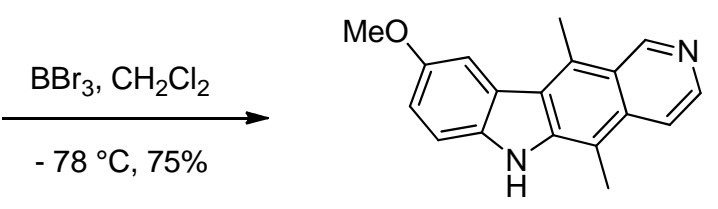

30

Scheme 26. Synthesis of 9-methoxyellipticine $\mathbf{3 0 .}$

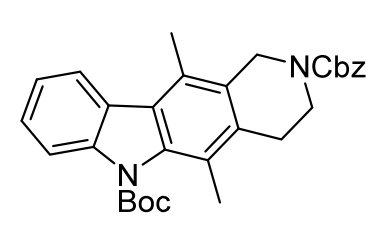

$122 a$

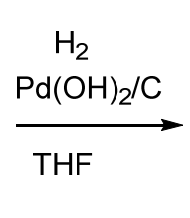

[<smiles>Cc1c2c(c(C)c3c1[nH]c1ccccc13)CNCC2</smiles>

125

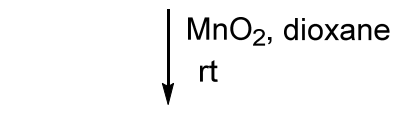<smiles>Cc1c2c(c(C)c3c1[nH]c1ccccc13)C=NCC2</smiles>

126; $70 \%$
$127 ; 75 \%$

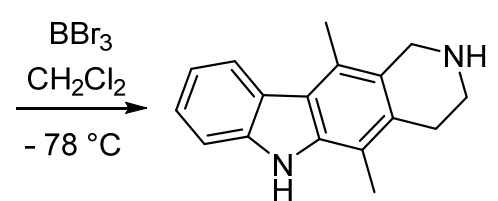

128; $65 \%$

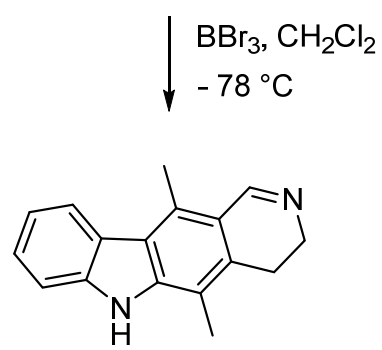

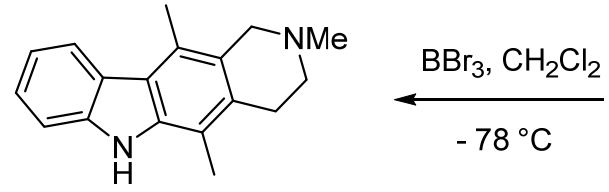

$130 ; 65 \%$

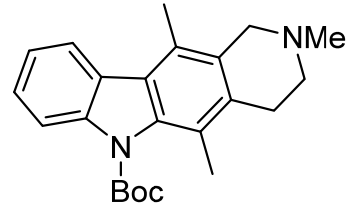

$129 ; 75 \%$

Scheme 27. Synthesis of $\mathbf{1 2 8}$ and $\mathbf{1 3 0 .}$ 
Next, carbazole 122a was converted to 3,4-dihydroellipticine ( $\mu$-alkaloid D) 127, 1,2,3,4tetrahydroellipticine 128 and 2-methyl-1,2,3,4-tetrahydroellipticine 130 (Scheme 27). Removal of the $\mathrm{N}$-Cbz group of $122 \mathrm{a}$ by catalytic hydrogenation provided amine 125 , which was then treated with $\mathrm{BBr}_{3}$. $\mathrm{This}$ sequence of transformations gave 1,2,3,4-tetrahydroellipticine $\mathbf{1 2 9}$ in 65\% yield from 122a. Moreover, catalytic reduction of carbazole $\mathbf{1 2 2 d}$ produced 129 in a one-pot reaction. Additionally, amine 125 was oxidized with $\mathrm{MnO}_{2}$ to give imine 126. Treatment of 126 with $\mathrm{BBr}_{3}$ provided 3,4-dihydroellipticine 127 in $75 \%$ yield. The $\mathrm{N}-\mathrm{Cbz}$ group of $122 \mathrm{a}$ was readily reduced to the $\mathrm{N}$-Me group with DIBAL in THF at room temperature, leading to compound $\mathbf{1 2 9}$ in $75 \%$ yield. The $N$-Boc group was then removed with $\mathrm{BBr}_{3}$ to give 2methyl-1,2,3,4-tetrahydroellipticine 130.

The total syntheses of olivacine 48, 3,4-dihydroolivacine 140, ( \pm )-janetine 137 and ( \pm )-gutambuine 135 were undertaken starting from carbazole $\mathbf{1 2 2 f}$. To transform $122 \mathrm{f}$ into carbazole 133, the $\mathrm{N}$-Cbz group of $122 \mathrm{f}$ was removed by catalytic hydrogenation, and resulting amine 131 was subjected, without purification, to oxidation with $\mathrm{MnO}_{2}$ to yield 132 in $70 \%$ yield from 122f. Next, the Me group was introduced into the C-1 position of 132. Treatment of $\mathbf{1 3 2}$ with $\mathrm{ClCO}_{2} \mathrm{Bn}$ in THF at room temperature, followed by the addition of $\mathrm{MeMgBr}$, readily provided 133 in $80 \%$ yield. Conversion of 133 to ( \pm )-guatambuine 135 was carried out (Scheme 28) by first converting the $\mathrm{N}$-Cbz group of $\mathbf{1 3 3}$ to its NMe congener with DIBAL; 134 was generated in $80 \%$ yield. Removal of the $N$-Boc group in 134 was effected with $\mathrm{BBr}_{3}$ to provide ( \pm )-guatambuine 135 in $60 \%$ yield. Additionally, the $\mathrm{N}$-Boc group in $\mathbf{1 3 3}$ was cleaved by treatment with $\mathrm{Cs}_{2} \mathrm{CO}_{3}$ in refluxing $\mathrm{MeOH} / \mathrm{THF}$ to render 135a. A conformational inversion of the D-ring, accompanied by inversion of the nitrogen at the 2position was observed.

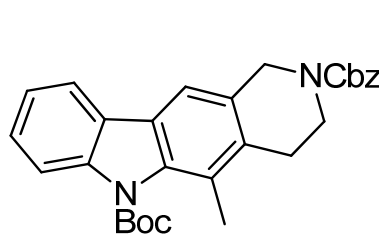

$122 f$

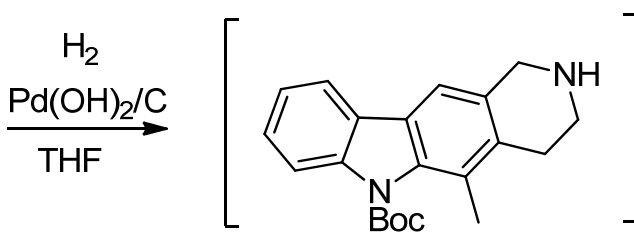

131

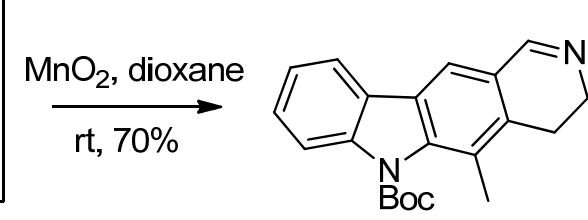

132

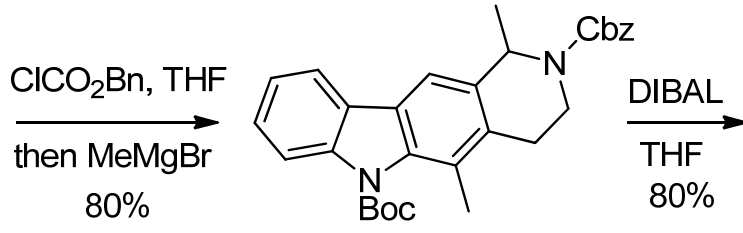

133<smiles>Cc1c2c(c(C)c3c1[nH]c1ccccc13)C(C)N(C)CC2</smiles>

134

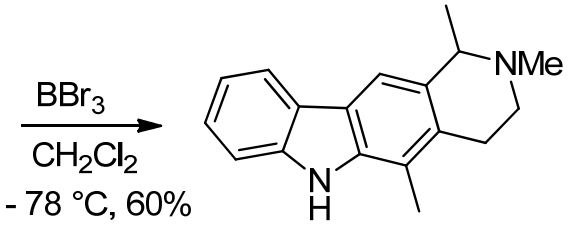

(士)-135

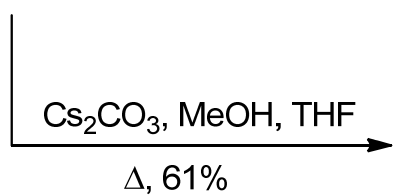

$\Delta, 61 \%$

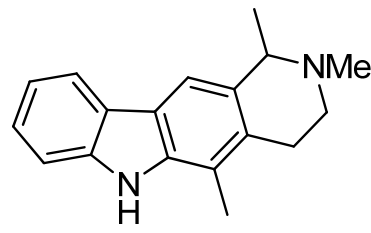

(士)-135a

Scheme 28. Synthesis of ( \pm -135. 
Next, 133 was converted to ( \pm )-janetine 137 (Scheme 29 ) by removal of the $N$-Cbz group using catalytic hydrogenation. Resulting amine 136 was subjected, without purification, to reaction with $\mathrm{BBr}_{3}$ to produce ( \pm )janetine 137 in $50 \%$ yield. Additionally, amine 136 was oxidized with a fivefold excess of $\mathrm{MnO}_{2}$. This oxidation provided imine 138 in $70 \%$ yield and 139 in 5\% yield from 133. A 20-fold excess of $\mathrm{MnO}_{2}$ and prolonged reaction time $(7 \mathrm{~d})$ sufficed for the oxidation of 136 at room temperature, affording 139 in $72 \%$ yield from 133. Removal of the $\mathrm{N}$-Boc group in 139 with $\mathrm{BBr}_{3}$ provided olivacine 48 in $60 \%$ yield. On the other hand, 3,4dihydroolivacine 140 was generated by treatment of 138 with $\mathrm{BBr}_{3}$.

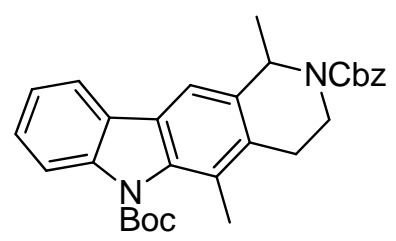

133<smiles>Cc1c2c(cc3c1[nH]c1ccccc13)CCCC2C(C)O</smiles>

136<smiles>Cc1c2c(cc3c1[nH]c1ccccc13)C(C)NCC2</smiles>

(士)-137

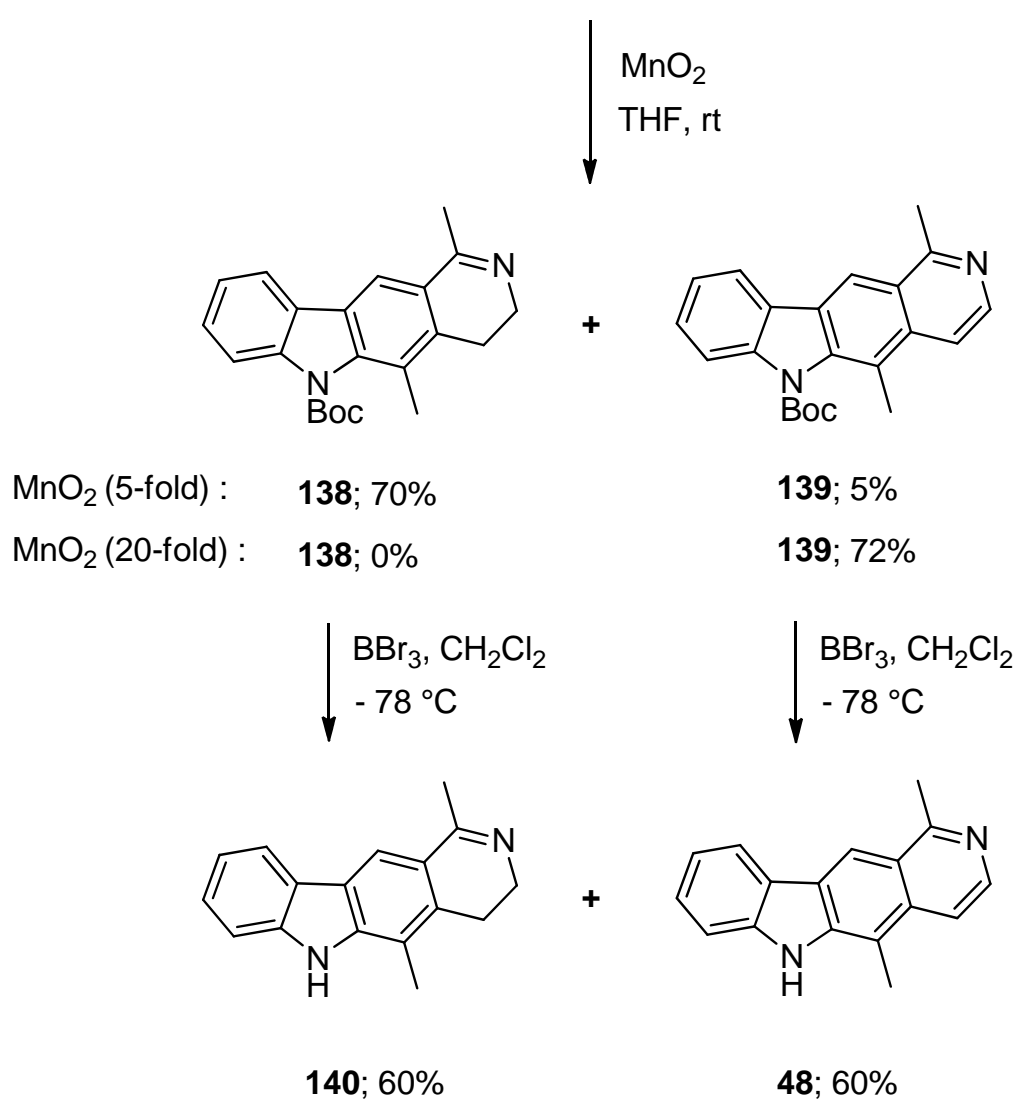

Scheme 29. Synthesis of 140,48 and $( \pm)-137$.

In 2017, Hatae et al. ${ }^{48}$ developed a concise protocol for the synthesis of ellipticine quinone as outlined in scheme 31. The three-component $\mathrm{Pd}$-catalyzed cross-coupling reaction between 3-iodoindole-2-carbaldehyde 144 and alkenyl tributyltin 143 under CO (1 atm) atmosphere was conducted in DMF at $70{ }^{\circ} \mathrm{C}$ to provide 3acryloylindole 145 in $64 \%$ yield. The alkenyl tributyltin required 143 is obtained by treatment of aminoacetaldehyde diethyl acetal with $p$-toluenesulfonyl chloride and $\mathrm{NEt}_{3}$ leading to the $p$ toluenesulfonamide 141 in $76 \%$ yield. This latter was subjected to alkylation with propargyl bromide to give 
the propargylamine 142 in $74 \%$ yield. Subsequently, 142 was subjected to Pd-catalyzed hydrostannylation with tributyltin hydride to afford the desired alkenyl tributyltin 143 in 97\% yield (Scheme 30).<smiles>CCOC(CN)OCC</smiles>

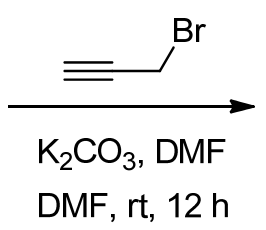

$74 \%$

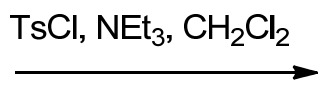

$0^{\circ} \mathrm{C}, 1 \mathrm{~h}$

$76 \%$

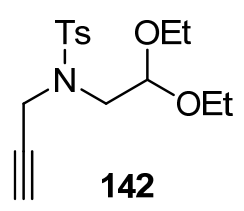

142<smiles>CCOC(CN[As])OCC</smiles>

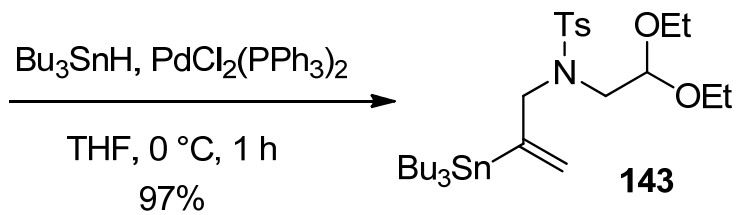

Scheme 30. Synthesis of alkenyl tributyltin.

The Grignard reaction of $\mathbf{1 4 5}$ with vinylmagnesium bromide afforded the allyl alcohol 146. Treatment of 146 with grubbs $2^{\text {nd }}$ generation catalyst directly afforded the carbazole-1,4-quinone 147 in $66 \%$ yield. Finally, compound 147 was subjected to cyclization with $6 \mathrm{M} \mathrm{HCl}$ by conventional heating. The desired ellipticine quinone 12 was obtained in 35\% yield. Under microwave irradiation, the yield improved and 12 was obtained in $67 \%$ yield. Furthermore, cyclization of 147 with $6 \mathrm{M} \mathrm{HCl}$ under microwave irradiation gave ellipticine quinone 12 as the sole product in $90 \%$ yield. Thus, the synthesis of ellipticine quinone 12 was achieved in $34.6 \%$ overall yield in four steps (Scheme 31 ). 


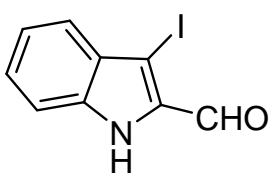

144

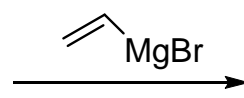

THF, $0{ }^{\circ} \mathrm{C}$

$91 \%$

$\mathrm{HCl}$, 1,4-dioxane

$\mathrm{MW}, 100^{\circ} \mathrm{C}$ $90 \%$
143, $\mathrm{CO}$ (1 Atm), BHT

$\mathrm{PdCl}_{2}$ (dppf), DMF, $70^{\circ} \mathrm{C}$

$64 \%$<smiles>C=CC(O)c1[nH]c2ccccc2c1C(=O)CN(C)CC(OCC)OCC</smiles>

146<smiles>O=C1c2ccncc2C(=O)c2c1[nH]c1ccccc21</smiles>

12<smiles>CCOC(C)CN1CC(C(=O)c2c(C=O)[nH]c3ccccc23)=CC1CC</smiles>

145
Grubbs II, $\mathrm{O}_{2}$

toluene, $70{ }^{\circ} \mathrm{C}$

$66 \%$<smiles>CCOCC(CN([AsH3])CC1=CC(=O)c2[nH]c3ccccc3c2C1=O)OCC</smiles>

147

Scheme 31. Synthesis of ellipticine quinone.

Recently, in 2017, ellipticine, olivacine and their five reduced natural variants were synthesized via a palladium-catalyzed tandem cyclization/cross-coupling reaction as the key step by Ishikura et al. ${ }^{49}$

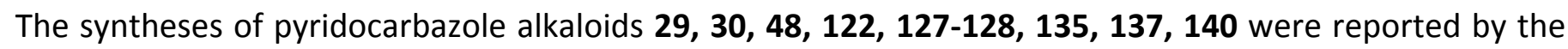
one-pot tandem cyclization/cross-coupling reaction of bromide 150 with indolylborate 149, which was generated in situ from indole 148, to produce hexatriene intermediate 120 . This was followed by $6 \pi-$ electrocyclization of $\mathbf{1 2 0}$ to produce pyridocarbazole core 121. Carbazole intermediates 121a were transformed into ellipticine 29, 9-methoxyellipticine 30, 3,4-dihydroellipticine 127, and 1,2,3,4tetrahydroellipticine 128. Olivacine 48, ( \pm )-guatambuine 135, ( \pm )-janetine 137, and 3,4-dihydroolivacine 140 were synthesized from common intermediate 122 derived from 121b (Scheme 32).

The cytotoxicities of the synthetic alkaloids and their derivatives against HCT-116 and HL-60 cells were determined. Structural properties, such as the aromaticity of the D ring and the presence of a Me group at the $N(6)$ - and C(11)-positions, affected the activities of the compounds. 

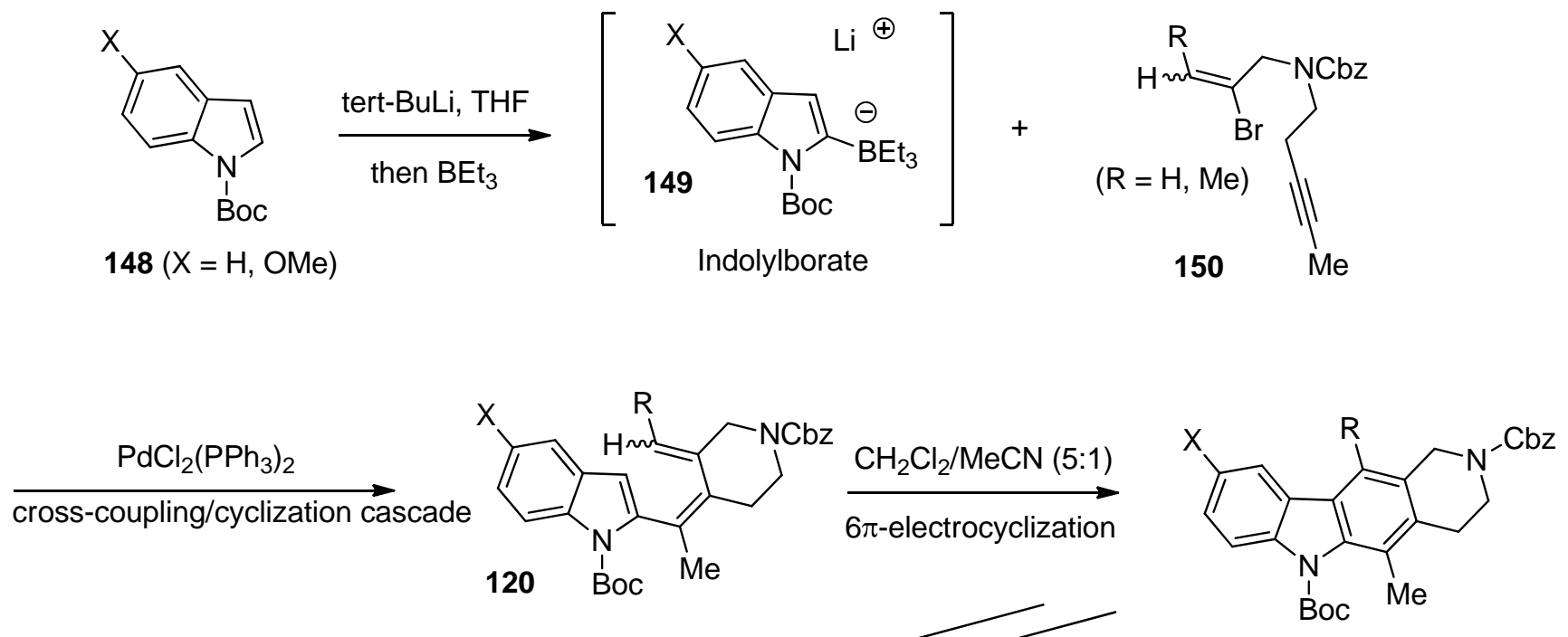

$121 \mathrm{a}(\mathrm{R}=\mathrm{Me}, \mathrm{X}=\mathrm{H}, \mathrm{OMe})$

121b $(R=X=H)$<smiles>[R]c1ccc2[nH]c3c(C)c4ccncc4c(C)c3c2c1</smiles>

$29(\mathrm{R}=\mathrm{H})$ Ellipticine $30(\mathrm{R}=\mathrm{OMe})$ 9-Methoxyellipticine<smiles>Cc1c2c(c(C)c3c1[nH]c1ccccc13)C=NCC2</smiles><smiles>Cc1c2c(c(C)c3c1[nH]c1ccccc13)CCNC2</smiles>

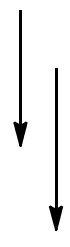

127 3,4-Dihydroellipticine 128 1,2,3,4-Tetrahydroellipticine<smiles>CC(=O)n1c2ccccc2c2cc3c(c(C)c21)CCN(C(=O)OCc1ccccc1)C3C</smiles><smiles>Cc1nccc2c(C)c3[nH]c4ccccc4c3cc12</smiles>

48 Olivacine<smiles>[R]N1CCc2c(cc3c([nH]c4ccccc43)c2C)C1[CH]</smiles>

135 Guatambuine $(\mathrm{R}=\mathrm{Me})$ 137 Janetine $(\mathrm{R}=\mathrm{H})$

Scheme 32. Synthetic scheme for pyrido[4,3-b]carbazole alkaloids.

\section{Conclusions}

The present review offers an up-to-date literature on the latest syntheses of ellipticine and ellipticine derivatives reported during the last years. Several of these syntheses may be useful, and in particular Hatae et 
al. $^{48}$ offers an attractive, short and efficient preparation of ellipticine quinone and its analogs. Overall, the interest in ellipticines and related pyridocarbazoles continue to expand given the diversity of structure and emerging bioactivity inherent in this compound class.

\section{Acknowledgements}

This work has been financially supported by the CNRS and the Ministère de l'Enseignement Supérieur et de la Recherche.

\section{References}

1. Stiborova, M.; Stiborova-Rupertova, M.; Borek-Dohalska, L.; Wiessler, M.; Frei, E. Chem. Res. Toxicol. 2003, 16, 38.

https://doi.org/10.1021/tx0200818

2. Stiborova, M.; Breuer, A.; Aimova, D.; Stiborova-Rupertova, M.; Borek-Dohalska, L.; Wiessler, M.; Frei, E. Int. J. Cancer 2003, 107, 885.

https://doi.org/10.1002/ijc.11511

3. Kouadio, K.; Chenieux, J. C.; Rideau, M.; Viel, C. J. Nat. Prod. 1984, 47, 872. https://doi.org/10.1021/np50035a022

4. Poljakova, J.; Hrebackova, J.; Dvorakova, M.; Moserova, M.; Eckschlager, T.; Hrabeta, J.; Gottlicherova, M.; Kopejkova, B.; Frei, E.; Kizek, R.; Stiborova, M. Neuroendocrinol. Lett. 2011, 32, 101.

5. Gopal, M.; Shahabuddin, M. S. India J. Med. Res. 2004, 119, 198.

6. Garbett, N. C.; Graves, D. E. Curr. Med. Chem. Anti-cancer Agents 2004, 4, 149. https://doi.org/10.2174/1568011043482070

7. Goodwin, S.; Smith, A. F.; Horning, E. C. J. Am. Chem. Soc. 1959, 81, 1098.

8. Gribble, G. W.; Saulnier, M. G. Heterocycles 1985, 23, 1277. https://doi.org/10.3987/R-1985-05-1277

9. Kansal, V. K.; Potier, P. Tetrahedron 1986, 42, 2389. https://doi.org/10.1016/0040-4020(86)80002-3

10. May, C.; Moody, C. J. J. Chem. Soc. Perkin Trans. I 1988, 247. https://doi.org/10.1039/p19880000247

11. Davis, D. A.; Gribble, G. W. Tetrahedron Lett. 1990, 31, 1081. https://doi.org/10.1016/S0040-4039(00)88731-6

12. Gribble, G. W. Advances in Heterocyclic Natural Product Synthesis 1990, 1, 43-94.

13. Gribble, G. W.; Keavy, D. J.; Davis, D. A.; Saulnier, M. G.; Pelcman, B.; Barde, T. C.; Sibi, M. P.; OLsaon, E. R.; Bel Bruno, J. J. J. Org. Chem. 1992, 57, 5878.

https://doi.org/10.1021/jo00048a021

14. Marsais, S.; Pineau, Ph.; Nivolliers, F.; Mallat, M.; Turck, A.; Godard, A.; Queguiner, G. J. Org. Chem. 1992, $57,565$.

https://doi.org/10.1021/jo00028a032

15. Ruckdeschel, J. C.; Modi, S. P.; Hamouly, W. E.; Portuese, E.; Archer, S. J. Med. Chem. 1992, 35, 4854. https://doi.org/10.1021/jm00104a011

16. Sha, C. K.; Yang, J. F. Tetrahedron 1992, 48, 10645. https://doi.org/10.1016/S0040-4020(01)88360-5 
17. Blechert, S.; Knier, R.; Schroers, H.; Wirth, T. Synthesis, Domino Reactions- New Concepts in the Synthesis of Indole Alkaloids and Other Polycyclic Indole Derivatives 1995, 592-604.

18. Miki, Y.; Tada, Y.; Yanase, N.; Hachiken, H.; Matsushita, K. Tetrahedron Lett. 1996, 37, 7753. https://doi.org/10.1016/0040-4039(96)01768-6

19. Poumaroux, A.; Bouaziz, Z.; Fillion, H.; Domard, M.; Giraud, J.; Petavy, A. Chem. Pharm. Bull. 1999, 47, 643.

https://doi.org/10.1248/cpb.47.643

20. Ishikura, M.; Hino, H.; Yaginuma, T.; Agata, I.; Katagiri, N. Tetrahedron 1999, 56, 193. https://doi.org/10.1016/S0040-4020(99)01016-9

21. Ishikura, M.; Hino, H.; Katagiri, N. Heterocycles 2000, 53, 11. https://doi.org/10.3987/COM-99-8759

22. Diaz, M.; Cobas, A.; Guitian, E.; Castedo, I. Eur. J. Org. Chem. 2001, 4543. https://doi.org/10.1002/1099-0690(200112)2001:23<4543::AID-EJOC4543>3.0.CO;2-\#

23. Kirsch, G. H. Curr. Org. Chem. 2001, 5, 507. https://doi.org/10.2174/1385272013375409

24. Pedersen, M.; Bowman, W. R.; Elsegood, M. R. J.; Fletcher, A. J.; Lovell, P. J. J. Org. Chem. 2005, 70, 10615.

https://doi.org/10.1021/jo0519920

25. Ho, T. L.; Hsich, S. Y. Helv. Chem. Acta 2006, 89, 111.

https://doi.org/10.1002/hlca.200690001

26. Dracinsky, M.; Sejbal, J.; Rygerova, B.; Stiborova, M. Tetrahedron Lett. 2007, 48, 6893. https://doi.org/10.1016/j.tetlet.2007.07.160

27. Liu, C. Y.; Knochel, P. J. Org. Chem. 2007, 72, 7106.

https://doi.org/10.1021/jo070774z

28. Moinet-Hedin, V.; Tabka, T.; Poulain, I.; Godard, M.; Lechevrel, M.; Saturninio, C.; Lancelot, J. C.; Le Talaer, J. Y.; Gauduchon, P. Anti-Cancer Drug. Des. 2000, 109.

29. Tylinska, B.; Jasztold-Howorko, R.; Mastalarz, H. K.; Wietrzyk, J. Arch. Pharm. 2008, 341, 351.

30. Miller, C. M.; McCarthy, F. O. RSC Advances 2012, 2, 8883. https://doi.org/10.1039/c2ra20584j

31. Meesala, R; Ezzat, M. O.; Mordi, M. N.; Mansor, S. M. Synlett 2014, 25, 2176. https://doi.org/10.1055/s-0034-1378518

32. Ramkumar, N; Nagarayan, R. Tetrahedron Lett. 2014, 55, 1104. https://doi.org/10.1016/j.tetlet.2013.12.098

33. Ramkumar, N; Raghavendra, M. S.; Nagarayan, R. Synlett 2014, 25, 2791.

https://doi.org/10.1055/s-0034-1379305

34. Ramkumar, N; Nagarayan, R. J. Org. Chem. 2014, 79, 736. https://doi.org/10.1021/jo402593w

35. Mori, R.; Kato, A.; Komenoi, K.; Kurasaki, H.; Iijima, T.; Kawagoshi, M.; Kiran, Y. B.;Takeda, S; Sakai, N.; Konakahara, T. Eur. J. Med. Chem. 2014, 82, 16.

https://doi.org/10.1016/j.ejmech.2014.05.032

36. Plug, J. P. M.; Koomen, G. J.; Pandit, U. K. Synthesis 1992, 1221.

https://doi.org/10.1055/s-1992-26342

37. Göcmentürk, M.; Hizhates, G; Ergün, Y. J. Heterocyclic Chem. 2016, 53, 767. https://doi.org/10.1002/ihet.2366 
38. Ergün, Y.; Patir, S.; Okay, G. Synth Commun. 2004, 34, 435.

https://doi.org/10.1081/SCC-120027282

39. Kutney, J. P.; Noda, M.; Lewis, N. G. Can. J. Chem. 1982, 60, 2426. https://doi.org/10.1139/v82-351

40. Sato, N; Kawai, Y.; Akaba, Y; Honma, S.; Sakai, N.; Konakahara, T. Heterocycles 2016, $92,664$. https://doi.org/10.3987/COM-16-13404

41. Plug, J. P. M.; Koomen, G.-J.; Pandit, U. K. Synthesis 1992, 1221.

https://doi.org/10.1055/s-1992-26342

42. Rasheed, Sk.; Rao, D. N.; Das, P. Asian J. Org. Chem. 2016, 5, 1499.

https://doi.org/10.1002/ajoc.201600411

43. Anil Kumar, K.; Prakash, K.; Devendra, K. D.; Vishwakarma, R. A.; Prasad, V. B; Das, P. Org. Biomol. Chem. 2015, 13, 1481.

https://doi.org/10.1039/C4OB02044H

44. Vann, K. R.; Ergün, Y.; Zencir, S.; Oncuoglu, S.; Osheroff, N.; Topcu, Z. Bioorg. Med. Chem. Lett. 2016, 26, 1809.

https://doi.org/10.1016/j.bmcl.2016.02.034

45. Karmakar, S.; Dixit, R.; Nath, A.; Kumar, S.; Karmakar, S. Indian J. Pharmacol. 2012, 44, 131. https://doi.org/10.4103/0253-7613.91887

46. Rizza, P.; Pellegrino, M.; Caruso, A.; lacopetta, D.; Sinicropi, M. S.; Rault, S.; Lancelo, J. C.; El-Kashef, H.; Lesnard, A.; Rochais, C.; Dallemagne, P.; Saturnimo, C.; Giordano, F.; Catalano, S.; Ando, S. Eur. J. Med. Chem. 2016, 107, 275. https://doi.org/10.1016/j.ejmech.2015.11.004

47. Itoh, T.; Abe, T.; Choshi, T.; Nishiyama, T.; Yanada, R.; Ishikura, M. Eur. J. Org. Chem. 2016, 2290. https://doi.org/10.1002/ejoc.201600246

48. Nishiyama, T.; Hatae, N.; Mizutani, M.; Yoshimura, T.; Kitamura, T.; Miyano, M.; Fujii, M.; Satsuki, N.; Ishikura, M.; Hibino, S.; Choshi, T. Eur. J. Med. Chem. 2017, 136, 1.

https://doi.org/10.1016/j.ejmech.2017.04.071

49. Itoh, T.; Hatae, N.; Nishiyama, T.; Choshi, T.; Hibino, S.; Yoshimura, T.; Ishikura, M. Med. Chem. Res. 2017, in press.

\section{Authors' Biographies}

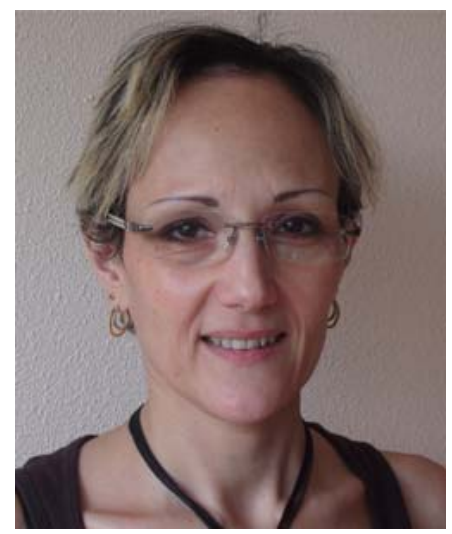

Malika Ibrahim-Ouali carried out her PhD under the supervision of Professor Gramain in Clermont-Ferrand (France) in 1996. The work was focused on the synthesis of alkaloids. She was a postdoctoral fellow with Prof. Knochel in 1996 
where she got her first training in organometallic chemistry. In 1997, she joined Professor H. P Husson's group at the ICSN (Paris) as a postdoctoral researcher. Since 1998, she is currently an assistant professor at Aix-Marseille University and her field of interest remains the total synthesis of natural compounds.

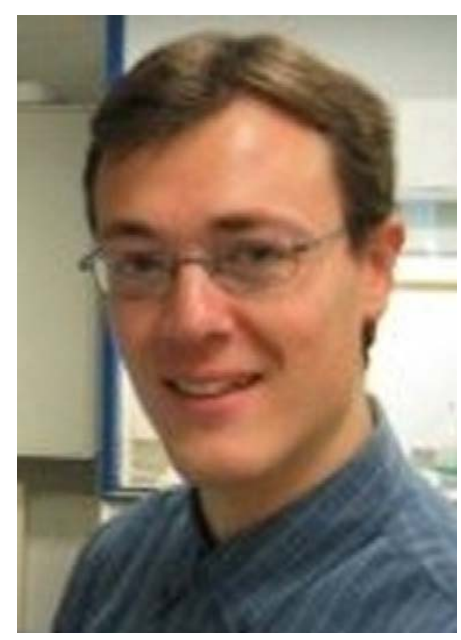

Frédéric Dumur received his PhD in chemistry in 2002 from the University of Angers (France) under the supervision of Professor Pietrick Hudhomme. After Post-Doctoral studies at the University of Groningen (The Netherlands), Reims Champagne-Ardennes (France) and Versailles Saint-Quentin-en-Yvelines (France), he joined the Faculty of Sciences at Aix-Marseille University in 2008, where he is currently working as an Associate Professor. His research interests include the synthesis of phosphorescent dopants for OLEDs and photoinitiators of polymerization. He co-authored about 160 publications and 5 book chapters. 